\title{
Janáčkova trnitá cesta k založení brněnské konzervatoře a jejímu zestátnění
}

\section{Janáček's Thorny Path Towards Foundation of the Brno Conservatoire and its Nationalization}

\author{
Jiří Zahrádka / jiri.zahradka@seznam.cz \\ Department of Musicology, Faculty of Arts, Masaryk University, Brno, CZ
}

\begin{abstract}
Right after the declaration of independent Czechoslovakia Janáček got busy carrying out his long-standing dream of founding a conservatoire in Brno. As a representative of the Brno Organ School he started negotiations with the music school of the Philharmonic Club of the Brno Beseda in November 1918 about the possible unification of the two institutions into a conservatoire. At the same time he addressed Professor František Weyr, a leading cultural figure and deputy at the National Assembly that should itself produce an initiative to found a conservatiore in Brno. This request reached the meeting of the National Assembly on 10 December 1918 and a resolution approved that the government does all necessary action to urgent establishment of a conservatiore in Brno. Highly difficult negotiations started with many bodies involved: cultural comission of the National Assembly, Ministery of Education and National Enlightenment, Union for Improvement of Church Music in Moravia (founder of the Brno Organ School), The Brno Beseda, Union of Music Estates, and also the Prague conservatiore that had been demanding nationalization for some time. Janáček's idea at the very beginning was the conception of a high-school institute of music research based on psychology. This idea, however, had no positive response. After many negotiations and compromises a provisionally private conservatoire was founded in Brno in September 1919 with high state subsidy and an agreement that it would become a state institution if it proves successful. It was then divided into an elementary school, a conservatoire and a higher masterclass. Leoš Janáček became head of the school. Shortly afterwards the Prague conservatoire was nationalized as a secondary school with high school masterclass. This raised an outrage among the MPs from Moravia, trustees and teachers of the Brno conservatoire. Thanks to these protests the proposal of immediate nationalization of the Brno conservatoire got to the programme of the National Assembly as early as 16 January 1920. It was decided the the government prepare the appropriate law. This soon materialized and the Assembly nationalized the Brno conservatoire
\end{abstract}


on 22 March 1920, but only as a secondary school. So Janáček wasn't successful with his idea of a high school/university institute and was, moreover, appointed a professor of the Prague masterclass and thus lost any control over the Brno conservatoire. His pupil Jan Kunc was appointed its head. Immediately at the beginning of the school year 1920/21 Kunc replaced Janáček's method of teaching harmony that had been traditionally taught at the Brno Organ School for several dozens of years by Otakar Šín's method that was taught in Prague. Janáček, however, kept on dreaming about his conception of the conservatoire and at least managed to arrange a possibility of visiting lectures of aesthetics and experimental psychology at the Masaryk University for his students.

\section{Keywords}

music education, Leoš Janáček, Brno Conservatoire, František Weyr, Czechoslovak National Assembly, Jan Branberger, Jan Kunc

„A náhle tu byl 28. ř́jen. [...] - Jé, jé. Rakousko zkrachovalo! Je konec války, vojáci trhaji orlícky s ̌̌epic, každý si připiná trikoloru!- Jak to Leoš uslyšel, popadl kabát a letěl do města. [...] Když jsme se večer všichni sešli doma, bylo plno štěstí. Zdálo se nám, že nastal ráj na zemi. Nebude válka, nebudeme mít hlad, smály jsme se s Mářou - tehdy každý myslil v prvni řadě na jídlo. Leoš se nyni vytasil se vším, co věděl od Jana Herbena. A už měl svou myšlenku: přetvořit varhanickou školu na konzervatoř. Ustavičně o tom mluvil, přemýšlel a začal jednat s vlivnými lidmi. Byl úžasně štasten, pořád odbíhal do města. " ${ }^{1} \mathrm{Z}$ této kratičké vzpomínky Zdenky Janáčkové je zřejmé, jak prakticky ihned po vyhlášení samostatné Československé republiky začal tehdy již pětašedesátiletý Janáček uskutečňovat svou vizi moderního uměleckého učiliště. Pro Janáčka byla pedagogická činnost po většinu dosavadního života základním pilířem jeho snažení, zatímco skladatelské aktivity byly spíše důležitým doplňkem. Nebo spíše Janáčkův tvưrčí přístup představoval pedagogickou a teoretickou činnost jako přirozeně a neoddělitelně propojenou s tvorbou skladatelskou i literární. Za více než čtyřicet let pedagogické činnosti dospěl ke svébytnému pohledu na hudební vzdělání a na koncepci výuky. Tyto pedagogické a organizační zkušenosti nabyl na brněnském učitelském ústavu, ženském učitelském ústavu, starobrněnském gymnáziu, českém dívčím gymnáziu, v hudební škole Besedy brněnské, ale především na své varhanické škole. Z malého ústavu, zrrízeného v roce 1881 Jednotou pro zvelebení hudby na Moravě (dále JZCHM), vznikl díky Janáčkově tvrdošíjné píli a činorodosti v desátých letech 20. století respektovaný ústav s vlastní budovou, vynikajícími pedagogy, širokou škálou předmětů a hudebních oborů a především s osobitým, originálním způsobem výuky hudební teorie. Především během válečných let se však varhanická škola potýkala s vážnými finančními potížemi, takže Janáček stále naléhavěji pocitoval nutnost jejîho zestátnění či pozemštění (a v roce 1917 se o to také bez úspěchu pokusil). Není divu, že ihned po změně politické situace v roce 1918 začal naplňovat svůj letitý sen, zrrídit v Brně státní hudební konzervatoř. Prvním krokem, který Janáček nazval „Předehrou“, byla žádost o zestátnění varhanické školy

1 TRKANOVÁ, Marie. „Paměti: Zdenka Janáčková - můj život.“ Brno: Nakladatelství Šimon Ryšavý, 1998, s. 117. 
podaná hned 14. listopadu 1918 Národnímu výboru (nikoliv radě, jak udává Janáček) v Brně. ${ }^{2}$ Dalším krokem mělo být oslovení Ministerstva školství a národní osvěty (dále MŠNO), přičemž s prosbou o radu se Janáček obrátil dopisem ze 17. listopadu na Jana Herbena, vlivného novináře a politika, člena Národního výboru i Národního shromáždění československého (dále NSČ). ${ }^{3}$ Dopis zůstal patrně bez odpovědi, proto se Janáček poté obrátil na Františka Weyra, který byl významným brněnským kulturním činovníkem, milovníkem hudby a také Janáčkovým kolegou z nově se konstitujícího výboru Družstva českého Národního divadla v Brně, který se stal poslancem NSČ. Janáček jej požádal, aby žádost postoupil přímo tomuto vrcholnému státnímu orgánu. ${ }^{4}$ Weyr skutečně na 9. schůzi NSČ dle stenografického protokolu tento návrh podal: ${ }^{5}$

Zasedání Národního shromáždění československého roku 1918.

Tisk 175.

Návrh

posl. Dra Weyra a soudr., aby zř́zena byla konservatoř hudby v Brně.

O ústavy, podávající dokonalé vzdělání hudební, je dosud u nás zcela nedostatečně postaráno. Je nutno, aby národ tak hudební, jako československý, měl př́ležitost vzdělávati se všestranně v umění hudebním.

Podepsaní navrhují proto:

Vládě se ukládá, aby co nejdříve zřídila v Brně státní konservatoř hudby.

Návrh budiž přikázán odboru školskému.

V PRAZE dne 10. prosince 1918.

Dr. Weyr,

dr. Jaroslav Stránský, dr. Herben, dr. Schieszl, Rosenkranc, Viktor Dyk, dr. Fáček, dr. Vaněk, Mattuš, dr. Engliš, dr. Vrat. Černý, dr. Lukavský, dr. Franta, Heinrich, Machar, Viková-Kunětická, Jirásek, prof. dr. Syllaba, dr. Matoušek, dr. B. Němec, dr. Mareš, Boh. Fischer. ${ }^{6}$

Weyr sice ve svých pozdějších memoárech vzpomíná, že žádost na zřízení státní konzervatoře předložil NSČ o své vůli, bez impulzu brněnských hudebních kruhů. ${ }^{7}$ Ale jednak podal návrh spolu s dalšími, především moravskými poslanci, a jednak z Weyrova dopisu Janáčkovi ze 13. ledna 1919 vyplývá, že iniciativa patrně vzešla právě od Janáčka: „Záležitost zř́zeni Státni konservatoře v Brně mám stále v evidenci. Můj návrh byl príidělen

2 Janáčkův koncept připravený patrně pro brněnskou anketu v květnu 1919, Janáčkův archiv Moravského zemského muzea (dále JA MZM), sign. (staré sb. fondy) K 6, dále koncept dopisu uložený tamtéž, sign. V 142.

3 Dopis Leoše Janáčka Janu Herbenovi, 17. 11. 1918, Památník národního písemnictví, kopie JA MZM, sign. D 1822. Citováno z: ZAHRÁDKA, Jiří a kolektiv (ed.). Korespondence Leoše Janáčka [online]. Brno, 2016 [cit. 15. 4. 2018].

4 KUNC, Jan. Z historie brněnské konzervatoře. In Výroční zpráva za školní rok 1924/25, Brno: Nákladem Státní hudební a dramatické konzervatoře v Brně, 1925, str. 3. Viz též Janáčkův koncept patrně připravený pro brněnskou anketu v květnu 1919, je JA MZM, sign. (staré sb. fondy) K 6.

5 Přepis stenografického zápisu: http://www.psp.cz/eknih/1918ns/ps/stenprot/009schuz/s009001.htm (cit. 15. 4. 2018)

6 Tisk č. 175: http://www.psp.cz/eknih/1918ns/ps/tisky/t0175_00.htm (cit. 15. 4. 2018)

7 WEYR, František. Paměti 2; Za republiky (1918-1938). Brno: Atlantis, 2001, s. 314. 
školskému výboru ku podáni zprávy. Nejsem bohužel členem toho výboru, ale jsem v stálém styku s dotyčným referentem. Doufám, že přišti týden přijde mưj návrh na denni pořádek ve výboru a pak bez prütahu do plena. "8 Mezitím Janáček informoval MŠNO o krocích spojených se zřízením brněnské konzervatoře ve zprávě varhanické školy. ${ }^{9} \mathrm{~V}$ otázce zřízení konzervatoře však bylo nutné najít společnou řeč také s dalšími brněnskými hudebními školami. Hlavním partnerem varhanické školy (respektive samotného Janáčka) se tak stala hudební škola Filharmonického spolku Besedy brněnské (dále FSBB), později též okrajově i hudební škola Vesny. Janáček zahájil vyjednávání hned na počátku listopadu 1918, jak je zřejmé z dopisu Josefu Kolbingerovi, předsedovi Besedy brněnské:

„Velectěný pane!

přikládám stručný obsah naší rozmluvy nezávazné.

Výbor varhanické školy sejde se př́šsí týden v pondělí.

Obsah její bude mu sdělen.

Těšilo by mne, když by do té doby stanovisko Bes. br. bylo mi známo.

Snad zvíme do té doby i něco bližšího o možné koupi Robertova domu.

V dokonalé úctě

oddaný

Leoš Janáček

Brno, 5. listopadu, 1918

Nezávazný rozhovor dotýkal se:

1. Zřízení vysoké hudební školy i elementárních oddělení; má to být státním ústavem.

2. Organisací začít hned.

3. Získat k varhanické škole přilehlý dům (majetek Robertů Židlochovických) pro př́ŕśtí tento státní hudební útvar.

4. Podniky koncertní jsou různého rázu: jsou spolkové, jsou pořádány umělci samotnými neb konc. ředitelství je pořádají

Jsem náhledu, že život hudební vyžaduje plnou volnost v podnikání koncertním.

Výchova školská žádá ale pevnou vědecky a prakticky sevřenou osnovu.

Dodatek:

Základ příštího touženého vys. učiliště spatřuji v připojení k sobě varh. školy a hud. školou Bes. brněnské.“"10

Jednání to jistě byla složitá, jelikož bylo zapotřebí přesvědčit o své vizi jenom FSBB, ale také JZCHM, zřizovatelku varhanické školy, kde ovšem měl Janáček zásadní a snad i poslední slovo. Dohoda o společném postupu obou škol i jejich zřizovatelů byla patrně v hrubých rysech předjednána již koncem roku 1918, jelikož Janáček počítal se vkladem

8 Dopis Františka Weyra Leoši Janáčkovi, 13. 1. 1919, JA MZM, sign. D 296. Citováno z: ZAHRÁDKA, Jiří a kolektiv (ed.). Korespondence Leoše Janáčka [online]. Brno, 2016 [cit. 15. 4. 2018].

9 Koncept dopisu Leoše Janáčka MŠNO, 15. 12. 1918, JA MZM, sign. V 141.

10 Dopis Leoše Janáčka Josefu Kolbingerovi, 15. 12. 1918, JA MZM, sign. D 1502. Citováno z: ZAHRÁDKA, Jiř́i a kolektiv (ed.). Korespondence Leoše Janáčka [online]. Brno, 2016 [cit. 15. 4. 2018]. 
obou spolků při koncepci základů organizační struktury. ${ }^{11}$ Dne 1. ledna 1919 Janáček zapsal, že JZCHM je ochotna přenechat po vzájemné dohodě budovu stávající varhanické školy na Kounicově ulici a FSBB by zase předal nové konzervatoři svůj notový archiv a hudební nástroje.

Nejpodstatněǰši však pro Janáčka bylo, prosadit na nově vznikající konzervatoři svou vizi výuky. Konzervatoř přitom chápal jako vysokoškolský ústav se způsobem výuky postaveném na teoretických a vědeckých oborech jako hudební psychologie, studium fonetiky, hudební vědy atd., které byly dříve doménou škol univerzitního typu. Tento přístup v mnohém uplatňoval již na varhanické škole, ale v nových podmínkách jej chtěl prosadit mnohem zásadněji. Několik skutečností však takové koncepci bránilo. Především šlo o pražskou konzervatoř. Ta rovněž usilovala o zestátnění, ale nikoliv o zásadní strukturální proměnu; koncepce stř̌ední školy s vy̌šsí mistrovskou školou pro ni byla ideálním řešením. Ministerstvo pochopitelně nemělo velký zájem na zřízení dvou konzervatoří se vzájemně odlišným statutem. Dalším momentem, který komplikoval situaci, bylo zřízení brněnské Masarykovy univerzity v lednu 1919, na jejíž Filozofické fakultě se s postupným zřízením oborů jako psychologie, fonetika či hudební věda jistě počítalo. Janáček se tak dostal se svou koncepcí brněnské konzervatoře jako vysokého hudebního učiliště do izolace a to vůči Praze i Brnu. Vypracováním postupu při zestátněné pražské a založení brněnské konzervatoře pověřil ministerský tajemník MŠNO Dr. Jan Branberger dva odborníky, Jana Kunce a Karla Hoffmeistera. Janáčkủv bývalý žák Jan Kunc však měl se svým dřívějším učitelem již několik let napjaté vztahy a kromě toho pobýval v Praze, kde se uplatnil v pražském Národním divadle. Janáčkův vliv na jeho rozhodování tak byl v dané chvíli naprosto nulový. Na jednání školského výboru NSČ 19. února 1919 byli vedle členů přizváni i dva výše uvedení experti. Ze stručného zápisu z jednání je zřejmé, že Kunc se vyslovil pro urychlené založení konzervatoře v Brně. Hoffmeister se z pohledu pražské konzervatoře vyslovil také pro zřízení brněnské školy s tím, že je nutné vyčkat až do doby zestátnění pražské konzervatoře z důvodu nízkého počtu kvalitních pedagogů. Ani Branberger nedoporučil okamžité založení nové státní konzervatoře, dokud nebude zcela dořešeno zestátnění konzervatoře pražské. $\mathrm{S}$ tím souhlasila i většina členů výboru. Za okamžité zřízení konzervatoře v Brně, už kvůli zájemcům ze Slovenska, se zasadil pouze Janáčkův prrítel ThDr. Alois Kolísek. Po debatě, které se účastnil Branberger i Kunc, bylo jednání přerušeno a přesunuto na další schůzi. ${ }^{12}$ Paradoxně jsme o závěrech jednání detailněji informováni z novinové zprávy, která vyšla o den později. Zde se uvádí, že oba experti, tedy Kunc a Hoffmeister, se vyslovili proti vysokoškolskému charakteru brněnského učiliště, a prosazovali pouze vyšši školu, podobně jako v Praze. ${ }^{13}$ Zachoval se nám také Kuncův rukopisný koncept vypracovaný pro kulturní komisi. Potvrzuje sice význam vzniku konzervatoře $\mathrm{v}$ Brně, ale zároveň zdůrazňuje velmi špatnou úroveň dosavadních hudebních učilišt tj. varhanické školy a hudební školy FSBB. Dosti nelichotivě se

11 Torzo návrhu organizační struktury, 1. 1. 1919, JA MZM, sign. (staré sb. fondy) K 6.

12 Zápis ze schůze školského výboru, 19. 2. 1919, Archiv poslanecké sněmovny (dále APS), fond RNS, spis. č. 1057.

13 ANONYM: Školské věci; Konzervatoř hudby v Brně - Evangelická fakulta v Praze. Lidové noviny, roč. 27, č. 51 (20. 2. 1919), s. 2. 
vyjadřuje i o Leoši Janáčkovi. S vysokou školou Kunc ve svém konceptu nepočítal a nepřímo nabídl své služby pro vedení nové střední školy (o tom viz níže). ${ }^{14} \mathrm{O}$ Kuncových snahách neměl Janáček patrně tušení, a tak reagoval pouze na novinovou zprávu z 20. února. V dopise neznámému adresátovi píše: „Vite, že jedná se o zřizeni konservatoře v Brně. $V$ té záležitosti vyslechl školský výbor dva znalce p. Kunce, korepetitora u Národního divadla, a p. Hoffmeistra, učitele klaviru na konservatoři v Praze. Oba se vyslovili proti vysokoškolskému rázu konservatoře. Je to tak, jak když slepý mluvi o barvách. Referentem v té záležitosti je Dr. Krejči, prosim Vás požádejte ho, aby byli v té záležitosti vyslechnuti ještě jini znalci. Vždyt' snad v té věci mohu mluvit i já a ne méně závažný hlas byla by filosofická fakulta university (hudebni vědy)! Je to na ostudu, jak si mohli troufat oni dva pánové a takové záležitosti vypovídat! Ale ovšem, je i ostudou, že byli tázáni. "15

Také dopis Janu Branbergerovi z 20. února 1919 dokládá, jak byl Janáček nespokojen s jednáním komise:

„Velevážený příteli!

Tu je pobouření po zprávě v Lid. Novinách o ,expertech“v školském výboru nár. shromáždění v záležitosti konservatoře brněnské!

Povážíme-li, že podstatou vysokoškolskou je učení historické, výzkumné hudebně-psychologické, akustické - pak třeba se ptát, jakým právem odmítali pp. Kunc a Hoffmeister ráz vysokoškolský hudební konservatoře brněnské? Jeden klavirista, druhý korepetitor divadelní! Tak přece při budování našeho hudebního života postupovat nelze dále.

Prosím Vás stůjte při závazném rozhodnutí vysokoškolského rázu brněnské konservatoře.

Nemůže být vybudována hned v úplnosti, ale základy může mít zdravější, jelikož lze je nově pořizovat.

Hůře to půjde u pražské konservatoře, jelikož jste nuceni přebírat zděděné poměry a osoby.

Nechci mluvit o osobnostech pro tyto výše připomenuté obory, ale až k tomu dojde, jistě se uzná, že jsou na svém místě a s náležitým věděním. Chci se zasadit o to, aby školský výbor nár. shromáždění v té záležitosti vyslechnul i mne a filosofickou fakultu university a prosím Vás přičinit se též v tom směru." 16

Janáčkův požadavek však nebyl vyslyšen a žádní noví experti na schůzi školského výboru 12. března nebyli ani zmíněni. Naopak byla vypracována zpráva podle původního expertního znění. ${ }^{17}$ Zprávu ze školského výboru přinesly obratem noviny již 13 . března. ${ }^{18}$ Školský výbor ústy zpravodaje poslance F. V. Krejčího přednesl 8. dubna 1919 zprávu

14 Rukopisné memorandum Jana Kunce, Oddělení dějin hudby Moravského zemského muzea (dále ODH MZM), G 6889b.

15 Dopis Leoše Janáčka neznámému, 20. 2. 1920, sign. B 2245. Citováno z: ZAHRÁDKA, Jiří a kolektiv (ed.). Korespondence Leoše Janáčka [online]. Brno, 2016 [cit. 15. 4. 2018].

16 Dopis Leoše Janáčka Janu Branbergerovi, 20. 2. 1919, JA MZM, sign. B 1446. Citováno z: ZAHRÁDKA, Jiří a kolektiv (ed.). Korespondence Leoše Janáčka [online]. Brno, 2016 [cit. 15. 4. 2018].

17 Zápis ze schůze školského výboru, 12. 3. 1919, APS, fond RNS, spis. č. 1062.

18 ANONYM: Školské věci; Konzervatoř hudby v Brně - Evangelická fakulta v Praze. Lidové noviny, roč. 27, č. 72 (13. 2. 1919), s. 3. 
z 19. března (Tisk 661) ${ }^{19}$ NSČ, ve které se jednoznačně doporučovalo zřídit v Brně konzervatoř, už vzhledem ke geografickým důvodům, nebot’ nová konzervatoř měla sloužit nejenom posluchačům z Moravy, ale také Slovenska. Postup měl být vzhledem k pražské konzervatoři následovný:

„Ve školském výboru byly uváženy všecky tyto důvody, které mluví pro brzké zřízení hudební konservatoře v Brně. Vyslechnuti byli však také hudební znalci, i bylo nutno přiznati oprávněnost některým jejich námitkám. Zejména poukazovali k tomu, že nemáme ještě dostatečně vybudovanou jedinou svou konservatoř, pražskou. Ta musila býti po převratu náležitě zčeštěna a nalézá se dosud ještě v přechodném procesu, a směruje se k jejímu sestátnění. I celé studium, celá organisace toho to ústavu musí býti teprve přizpůsobena podmínkám dnešního vývoje hudebního. Tato reforma pražské konservatoře není dosud skončena a jest nutno, aby jí věnoval náš stát všemožnou péči, a teprve podle zkušeností s touto konservatoří lze zříditi konservatoř druhou. Mimo to není po mínění hudebních znalců dnes na pražské konservatoři přílišný nadbytek žactva.

Také v celém národě není, máme-li dáti na jejich hlas, právě přebytku kvalifikovaných učitelských sil, který by přímo volal po zřízení učiliště druhého. Poměry ty zajisté se změní, až pominou dnešní přechodné a kritické poměry, pak zajisté se vytvoří jak v Praze, tak i v Brně docela příznivé základy pro rozvoj vyšších hudebních učilišt. Tu pak zajisté jest nutno žádati, aby k zřízení druhé konservatoře co nejdříve bylo přistoupeno a aby tato konservatoř co nejdřive byla sestátněna.

Školský výbor, uváživ důvody, které mluví pro zřízení hudební konservatoře v Brně, ale maje také na zřeteli všecky tyto těžké a svízelné dnešní poměry, umění nepříznivé, usnesl se na této resoluci:

„Vláda se vyzývá, aby přiměřeným způsobem zvýšila státní subvence pro pražskou konservatoř a pro varhanickou školu v Brně i pro tamní hudební školu Filharmonické Besedy. Ministerstvo školství se pověřuje, aby navázalo spojení obou těchto škol a dalo podnět k zřízení státní konservatoře hudby v Brně. Zároveň se vláda vyzývá, aby v nejbližší době sestátnila konservatoř hudby v Praze. “20

Tento postup také následně NSČ většinově schválila. Přístup NSČ však vyvolal nevoli, jak je zřejmé z článku z 30. dubna uveřejněného v Lidových novinách, kde se anonymní pisatel pozastavuje nad tím, že brněnská konzervatoř má být subvencována a postátněna až po Praze. Nadto autor článku upozorňuje, že vybudování druhé konzervatoře po vzoru pražské bude vést k nežádoucí uniformitě umělecké výchovy a navrhuje naopak prioritní zřízení brněnské konzervatoře. ${ }^{21}$ Ačkoliv autor nebyl jmenován, pravděpodobné je, že byl z brněnského, janáčkovského okruhu. Jistě ani sám navrhovatel, poslanec Dr. František Weyr, který nebyl členem školského výboru, nebyl tímto postojem nadšen.

Diskuze, jaký charakter by měly mít konzervatoře, však neustávaly. Pražská se jednoznačně klonila k typu hudební školy středoškolského charakteru s vyšší (později vysokou) mistrovskou školou. Janáček byl naprosto jiného názoru a chtěl vymanit konzervatoř

19 Tisk 661: https://www.psp.cz/eknih/1918ns/ps/tisky/t0661_00.htm (cit. 15. 4. 2018)

20 Přepis stenografického zápisu: https://www.psp.cz/eknih/1918ns/ps/stenprot/043schuz/s043006.htm (cit. 15. 4. 2018)

21 ANONYM: Umění - osvěta - školství. Lidové noviny, roč. 27, č. 119 (30. 2. 1919), s. 2-3. 
z ryze praktického zaměření a povýšit školu na vysokoškolský, hudebně-vědecký ústav. Byl toho názoru, že škola nemá vychovávat pouze praktické hudebníky, nýbrž že má mít daleko širší záběr. Dochovalo se několik Janáčkových náčrtů koncepcí, v nichž si ujasňuje charakter svého učiliště, přičemž nejucelenější, patrně z konce roku 1918, nechal opsat na psacím stroji jako výchozí materiál pro jednání:

$$
\begin{aligned}
& \text { „Konservatoř hudby } \\
& \text { v Brně }
\end{aligned}
$$

Návrh na zřízení státní konservatoře hudby, jako vysoké školy hudební, v Brně

Učení na této vysoké škole hudební zabírat má výzkum hudebních prvků naší mluvy, zabírat má dílo hudební všeho národa: národní píseň, všechnu vědu, theorii a techniku hudební.

Dá vyspělé a znalé reprodukční umělce, jak divadlu, tak koncertním síním, uzná v něm tvưrčí duch skladatelský. Nezapomíná se, aby zákoutí našich dědin mělo přiměřený požitek hudební.

Vzdělá učitelstvo hudební a s ním, dá národu ochranu jeho písní: zušlechtující požitek do divadel a koncertních síní městských vnese vzdělanými dirigenty, vychová skladatele pro závod světový a na zabezpečení hudebního věhlasu našeho.

Čítá vždy jen s nadáním hudebním a nechce velkovýroby muzikantské. Přijímá ve svých učebnách i všechny, kdož milují hudbu pro zesílení citovosti člověka i kdož chtějí se v požitku jejím jen orientovati.

Není překážek k návštěvě učení: ani stáří, ani zaměstnání ani v stupních všeobecného vzdělání.

Konservatoř obsahuje:

a) Kursy vysokoškolské

b) Tř́leté učení theoretické

c) Technické školy hry na všech hudebních nástrojích

d) Škola zpěvu

e) Škola dramatické mluvy

f) Pomocné nauky.

Konservatoř zřizuje se školním rokem 1918/19 postupně; úplně má býti vybudována, jakmile zřízena bude filosofická fakulta university brněnské. Výkvět hudební inteligence české má býti získán k pedagogické činnosti, k výzkumné práci v oborech hudebních.

Organisace konservatoře v Brně má vyjíti z dosavadní Varhanické školy v Brně ve spojení s hudební školou filh. spolku B. B.

Přechodní ustanovení:

a) Výše jmenované školy spojené převezmou se hned ve státní správu.

b) Též budova Varhanické školy s celým zařízením převezme se hned ve státní majetek.

\section{Podrobná zařízení.}

Organisace

Konservatoře, jako vysoké školy hudební:

A.

a/ učení naukám a vědám hudebním, jež jsou dosud části filosofické fakulty universitní.

Vytýkáme z nich zvlášt: 
1/ přednášky o národní písni,

2/ přednášky a výzkumy o melodicko-rytmických složkách mluvy,

3/pokusná hudební psychologie.

(Roční kursy: Výsledek prací se publikuje.)

b/ Učení theoretická:

1/ úplná nauka o souzvucích a jejich spojích, o tónině a vztazích tónin,

2/ nauka o sčasování včetně se zjevy tzv. kontrapunktu,

3/ osnovy harmonické závěrové, modulační.

4/ nauka o melodii: motiv, imitace, variace.

5/ nauka o užitých formacích skladebních.

(Třileté období učební)

c/ Pomocné nauky:

1/ akustika,

2/ hudební psychologie,

3/ dějiny hudby.

/Tř́leté období učebné v každém z těchto předmětů/

B.

Předměty technicky hudební.

a/ Plný výcvik hry na všech hudebních nástrojích:

$1 /$ varhan /tř́ileté období uč./

2/ klavíru /šestileté období uč./

3/ šmytcových nástrojů: houslí, cella, kontrabassu /5 leté obd. uč./

4/ dechových nástrojů:

a) dřevěných: Flauta, Oboe, Clarinett, Fagott,

b) žestových: Trubka, Corna, Pozaun,

c) bicích: Tympani

b/ Zpěv liturgický, světský, divadelní i koncertní, sólový i sborový.

c/ Dramatická četba a mluva.

Sbor učitelský:

Sbor učitelský skládá se z profesorů těchto oborů a vyučovacích předmětů:

1/ obor pokusné hudební psychologii, profesor

2/ obor studia lidové písně, prof.

1.

3/ obor studia mluvy, prof.

1.

4/ obor pro nauku o souzvucích a jejich spojích, prof.

1

pro s časování / rytmika/

5/ pro znalost kontrapunktu a fugy 
6/ pro hru klavírní, prof.

7/ pro hru houslovou, prof.

8/ pro hru cellovou, prof.

9/ pro hru na kontrabass

10/ pro dechové nástroje, prof.

11/ pro zpěv sólový, prof.

sborový, prof.

12/ pro dramatické čtení a mluvu
2.

2.

1.

1.

7/

1.

$1 /$

$1 /$

K profesorům přistupují dle potřeby, dle počtu přihlášených elévů jejich assistenti na výpomoc vyučovací.

Mimo profesorů ustanoveni jsou lektoři.

$1 /$ pro dějiny hudby

2/ pro paedagogiku a hudeb. psychol.

3/ pro akustiku

Zabezpečení životní abiturientů konservatoře

Abiturienti konservatoře mají nárok na případná hudební postavení a výkony v podnicích hudebních / divadla, opery, činohry, koncerty, místa učitelská, dirigentská, atd./ jež vydržovány a podporovány jsou z peněz a prostředků obecních a státních.

Administrativa:

Administrativu konservatoře vede tajemník konservatoře. Konservatoř řídí na nejkratší období studijní / tř́i let/ zvolený profesorským sborem rektor konservatoře.

\section{Konservatoř hudby v Brně \\ Všeobecná hlediska}

I.

Výchova hudební

Je jisté, že člověk prostý - jenž neví ani co je nota - má z hudby největší potěšení a radost. Není u něho studnice tohoto potěšení - citovost - kalena a omezována vtírajícími se do jasného vědomí všech těch představ, na něž už pouhý pohled na potištěnou notami stránku poukazuje.

I když „člověk z lidu“ jen prostě cítí hudbu, přece uchovává si tím i zdroj tvořivosti hudební. Lid, jenž noty neznal, složil si tisíce písní a zpívá si je, zase bez pomoci „not“.

Hudci z lidu bez znalosti not překvapují dovednou hrou na housle, na cymbal, na gajdy, ba i na jiné hudební nástroje.

Rytmus a melodie v lidové tvorbě hudební - oboje uznáváno za originální, rázovité - dělá, tvoří u něho všechno jeho vědomí všechen jeho duševní život né jen jakási část čistě tónová.

Hudební výchova lidu tím více stoupá, čím více hotových hudebních děl slyší: v prvé řadě jsou tu jeho písně světské a náboženské uložené v kancionálech. Ale i methoda, jǐž se těm písním má učit at' ve škole at’ v životě má býti jeho. Jistě to není methoda, jež jde po trnité cestě notace. 
Tato jeho methoda - pojímal píseň jako celek netrhaný na rytmická a melodická cvičení - patří i do škol národních.

Však i člověk rozsáhlého všeobecného vzdělání má tehdy „požitek“ z hudby nejčistší, dovede-li se oddat zcela nerušeně, bez odklonu, prostým tónovým dojmům bez všelikých příměsků.

Známo, že tak těšit se z hudby „vyškolení“ hudebníci nesvedou a že moderní skladatel nezná z hudby jiné radosti, než tvůrčí.

Z tohoto názoru plyne důležitost výchovy těch, jež mají provozovati díla hudební, dokonale provozovati. Z toho též ale vyplývá, že netřeba a nelze zaplaviti školskou výchovou hudební celý národ: Každý člověk má „srdce“, cit, dokud ho má, zůstává přístupen k účinkům hudby. To stačí lidem, jako národu.

Když jednotlivci chtějí mimo toho sami se zabavovati svou hrou, najdou si i cesty a času a způsobu. Jak organisace konzervatoře umožňuje dospěti i laikům v hudebním vzdělání:

Ale i laiků touha po hudebním vzdělání založena je na zvláštním nadání hudebním, jež neleží jen v ozvu citovém, ale jež ještě osvojuje všechny představy hudební do největší jasnosti, a jichž associaci jak mezi sebou tak s ostatní výplní vědomí mozek předně uskutečňuje.

Proto zůstává konservatoř otevřena sice všem a z těch - to všech vždy jen hudebně nadaným.

II.

Učení hudbě - v kterémkolvěk oboru je přístupno každému, at̉ jako výhradní studium, at jako doplňkové, bez ohledu na stáŕí, vzdělání, i pro prostou orientaci ve všech odvětvích a oborech hudebních je přípustno.

III.

Vzdělání hudební a všeobecné vzdělání.

T. zv. „nadání hudebni““ / ozva citová, affekční, na podnět/dojem, pocit/ tónový, at zevnější neb centrální/ - samo o sobě klade meze t. zv. Všeobecnému vzdělání. A naopak: obzvláště dramatická hudba dospívá svého pravdivého výrazu teprve při dokonalém vzdělaném myslím všeobecném.

IV.

a.

Uzrávat hudebně co nejdřive. Nemá býti překážkou všeobecné vzdělání: Každý obor hudební nevyžaduje stejného stupně všeobecného vzdělání - též netřeba v každém oboru dospěti až myšlení tvưrčího.

Nesporné, výjimečné nadání hudební - na př. při t. zv. „zázračných dětech“ dusit a zatěžovat mysl naukami středních škol - varhaníky venkovských chrámů i všemi vědomostmi měštanských školy - takové přílišné zatîžení naukami všeobecného vzdělání ničí v jádru živel citový, jeho výbušnost v afektu a bylo by na zkázu tvůrčí skladatelské činnosti.

Třeba tu doplňku hudebního učení zejména závaznými předměty

1) o slovesnosti české/literatura česká

2) dějin českých

3) všeobecné psychologie

4) akustiky

b.

Povolání učitelské v hudbě obzvláště ono na středních školách a učitelských ústavech, vyžaduje ale nejširšího všeobecného vzdělání. Připojením věd hudebních z filosofické fakulty universit dospěla by tato významu ku konservatoři vysoké škole hudební. 
Získá se posluchačů se všeobecným vzděláním středoškolským i s plným vzděláním hudebním. Potřebných širokých rozhledů nabyli by tu skladatelé dramatičtí dirigenti operní, spisovatelé a badatelé hudební.

\section{V.}

Učení hudební zabírá i mluvu českou, jak po její stránce hudební melodické, sčasovací, tak ve vztazích $\mathrm{k}$ posunkám a tvářnosti tak i vzhledem $\mathrm{k}$ associaci věcné těchto výrazů: $\mathrm{k}$ srozumitelnosti slova. Tímto učením dává se základ dramatické četbě a mluvě, průpravy činoherní.

VI.

Učivo theoretické a technické obmezuje se potřebou pro povolání hudební (ráz praktický), podává se ve své úplnosti věcné do dokonalosti technické (ráz vysokoškolský) a je i výzkumné, obzvláště po stránce hudebně psychologické.“22

Potřebné kroky k řešení otázky pražské a brněnské konzervatoře schválené NSČ byly předány do gesce vlády a tedy potažmo MŠNO. Za účelem reorganizace a zestátnění pražské konzervatoře hudby proto byla do Prahy na 6. května svolána tzv. anketa, kde o dané problematice hovořili odborníci z Čech a Moravy. ${ }^{23}$ Pražské ankety se účastnil z Brna dr. František Weyr a také Leoš Janáček. ${ }^{24}$ Pro anketu byl vydán materiál, který si Janáček důkladně prostudoval a opoznámkoval. ${ }^{25} \mathrm{Z}$ něj je patrné, jak zásadně se jeho vize brněnského ústavu lišila od koncepce pražské konzervatoře. To však nebyl jediný problém. Na společném postupu bylo nutné dohodnout se kromě hudební školy FSBB ještě s Jednotou hudebních stavů (dále JHS), která se měla na řešení problematiky založení brněnské konzervatoře také podílet a se kterou Janáček rozhodně neměl ideální vztahy. JHS ústy Antonína Hromádky iniciovala dopisem MŠNO ze 7. května schůzi, které se měli účastnit dva představitelé varhanické školy (Janáček, Tučková nebo Kvapil), dva hudební školy FSBB (Reissig, Petrželka) a dva JHS (Hromádka, Koblížek). ${ }^{26}$ Janáček zatím inicioval komorní schůzku zaměřenou již přímo na sepsání učebních osnov, přičemž se mu nijak nezamlouval nápad uspořádat anketu po vzoru Prahy, kde by se o charakteru nové konzervatoře mělo hovořit v širším plénu: „Po úradě s p. prof. Spilkou navrhujeme a prosíme Vás, abyste svolal na nedèli, 18. května redakční poradu asi pěti významných lidi, aby definitivni text řádu konservatoře sdělali. ,Anketa ' nová neměla by jiného výsledku než pražská. A záležitost chvátá. Nezbytně v konci června třeba vypsat zápis! Shodli jsme se v podstatě o všech závadách a jistě redakčni výbor

22 Strojopis koncepce, JA MZM, sign. (staré sb. fondy) K 3.

23 ANONYM: Konservatoř hudby v Praze. In Lidové noviny, roč. 27, č. 126 (7. 6. 1919), str. 6.

24 Dopis Leoše Janáčka Kamile Stösslové, 4. 5. 1919, JA MZM, sign. E 129. Citováno z: ZAHRÁDKA, Jiř́i a kolektiv (ed.). Korespondence Leoše Janáčka [online]. Brno, 2016 [cit. 15. 4. 2018].

25 Strojopisný materiál s Janáčkovými poznámkami, JA MZM, sign. (staré sb. fondy) K 2.

26 Dopis Jednoty hudebních stavů MŠNO, 7. 5. 1919, Národní archiv v Praze (dále NA), zn. MŠ, fond Ministerstvo školství, Praha, kart. 3410, inv. č. 330 Brno. 
za den svou práci vykoná. “27 Branberger se však v dopisu Janáčkovi z 15. května vyslovil proti takové schůzce a žádal nejprve uspořádání ankety: „Doporučuji Vám, abyste nejdřive si věc $v$ Brně se všemi hudebniky projednal - jak se stalo též v Praze - a pak sem návrh zaslal. Potom by mohla se odbývati př́slušná redakčni schưze. "28 Janáček však měl o koncepci konzervatoře jasno a nemínil svou vizi konfrontovat s moravskými odborníky, většinou hudebními praktiky propojenými s JHS, kterou zajímaly spíše praktické zájmy hudebníků než velkorysá vize vysokoškolského hudebně-vědného učiliště. Janáček nakonec anketu v Brně svolat musel, ale přednesl zde vlastní koncepci konzervatoře. ${ }^{29}$ Konala se v neděli 25 . května v brněnské varhanické škole a účastnilo se jí 40 odborníků, mezi nimiž nechyběli např. Jaroslav Kvapil, Václav Kaprál, Vilém Petrželka, František Neumann, Václav Štech, Rudolf Pavlata, Vilém Kurz, Osvald Chlubna, Karel Sázavský, Felix Rudiš či K. B. Jirák. ${ }^{30}$ Předsednictví se ujal František Weyr, jemuž se před zasedáním dostalo dvou materiálů; výsledek pražské ankety a Janáčkem vypracovaný písemný návrh na zřízení státní konzervatoře v Brně. ${ }^{31}$ Pravdou zůstává, že dle zápisu na schůzi hovořili v podstatě pouze dvě osobnosti, Weyr, který otázky pokládal, a Janáček, který své vize nekompromisně obhajoval. ${ }^{32}$ Svůj postoj za Jednotu hudebních stavů formuloval Antonín Hromádka a za hudební školu Besedy brněnské Ladislav Němeček. Weyr úvodem předestřel tři základní body, jež měla anketa vyřešit. Zaprvé, zda má být zř́izen jediný typ konzervatoře stejný pro Prahu i Brno. Zadruhé, zda má škola řešit poměr mezi hudební školou FSBB a varhanickou školou, potažmo zda má být konzervatoř zaměřena pouze na budoucí profesionální hudebníky, či zda má zřídit také elementární hudební školu. K tomuto bodu Antonín Hromádka za JHS navrhl, aby byla na konzervatoři zbudována elementární škola, která by připravovala žáky na studium konzervatoře, a Ladislav Němeček za hudební školu FSBB přednesl svůj elaborát týkající se náplně jednotlivých kursů. Posledním bodem, který inicioval Janáček, byla otázka, zda má mít konzervatoř ráz vysokoškolský, takže by se zde nevyučovaly pouze interpretační obory a běžné hudebně teoretické předměty, ale studium by zahrnovalo i některé vědecké obory. Janáček poukazoval na to, že pražská anketa se ničeho nedobrala, protože předložený návrh byl plný nelogičností. Pražská konzervatoř podle něj nebyla jednotného typu, protože v sobě zahrnovala střední školu a k tomu mistrovskou školu, která má mít vysokoškolský charakter, ale v podstatě mezi nimi není rozdíl. Janáček hájil typ jednotný, kde by se posluchač vzdělával v uceleném systému od počátku až k završení studia, přičemž tento jednotný typ vzdělání měl mít charakter vysokoškolský. Také zastával názor, že koncepce pražské a brněnské konzervatoře by se neměly zcela shodovat a měly by vycházet

27 Dopis Leoše Janáčka Janu Branbergerovi, 13. 5. 1919, JA MZM, sign. B 1452. Citováno z: ZAHRÁDKA, Jiří a kolektiv (ed.). Korespondence Leoše Janáčka [online]. Brno, 2016 [cit. 15. 4. 2018].

28 Dopis Jana Branbergera Leoši Janáčkovi, 15. 5. 1919, JA MZM, sign. B 2288. Citováno z: ZAHRÁDKA, Jiří a kolektiv (ed.). Korespondence Leoše Janácka [online]. Brno, 2016 [cit. 15. 4. 2018]. Koncept dopisu Jana Branbergera varhanické škole, 14. 5. 1919, NA, zn. MŠ, fond Ministerstvo školství, Praha, kart. 3410, inv. č. 330 Brno.

29 Strojopisný opis koncepce, NA, zn. MŠ, fond Ministerstvo školství, Praha, kart. 3410, inv. č. 330 Brno.

30 Prezenční listina, NA, zn. MŠ, fond Ministerstvo školství, Praha, kart. 3410, inv. č. 330 Brno.

31 Viz pozn. 22.

32 Rukopis zápisu ankety, JA MZM, sign. (staré sb. fondy) K 1. Strojopis, NA, zn. MŠ, fond Ministerstvo školství, Praha, kart. 3410, inv. č. 330 Brno. 
z místních daností. Co se týče stávajících brněnských hudebních škol, navrhoval Janáček, aby varhanická škola a její pedagogové tvořili základ nové konzervatoře. Otázku začlenění hudební školy FSBB do své vize konzervatoře jako institutu vysokoškolského navrhoval vyřešit vytvořením nového oboru hudebního vzdělání jako doplňku všeobecného vzdělání, do kterého by přešli pedagogové z hudební školy FSBB. K tomuto bodu jednání se vyslovil pouze Janáček a jeho argumentace je dle zápisu poměrně komplikovaná a místy obtížně srozumitelná. Pochopitelnější je jím předložený písemný návrh koncepce. Anketa se na závěr shodla na nutnosti zřízení konzervatoře v Brně již od školního roku 1919/20.

Hned další den Janáček o anketě informoval Branbergera:

„Včera, 25. května, odbývala se anketa o brněnské státní konservatoři v Brně za účasti vážných interessentů z Brna a z Moravy vůbec - počtem čtyřiceti.

Předsedal ji Dr. Weyr ${ }^{3}$.

Předložil jsem vypracovaný návrh všeho řádu konservatoře i učebných osnov.

Rozprava rozvržena na tři hlavní části:

a.) Typ konservatoře v podstatě stejný, at’ v Praze, at’ v Brně atd.

b.) poměr škol, filh. besedy a varhanické školy a jejich majetku ku státní konservatoři v Brně.

c.) ráz vysokoškolský státní konservatoře hudby.

Ve všem zřejmý byl souhlas v názorech.

V návrhu mém: zvláštního oboru vzdělávání hudebního jako doplňku všeobecného vzdělání, věcně vystižen návrh „stavů hudebních“ (elementárka hudební) i starosti filh. spolku o jejich žáky.

Tento obor je sice součástí konservatoře (cvičná škola, pokusný a badatelský význam), může být ale i samostatně zřízen.

Ku jednání přizval jsem stenografa. Ve středu dodá mi zápis všeho jednání.

Možno tedy svolati redakční výbor. Srovnal jsem pražský návrh s naším, odchylky jsem vytknul, odůvodnění jich sděláno - není tedy pochyby, že dojde se ku konečné stylisaci.

A když by snad o něčem shody mezi pražským nazíráním a našim nebylo docíleno - tož nemusí být konservatoře podobny jako vejce vejci a netřeba také hned v těchto bodech míti shody. At stroj jde - vyjde si už svůj hladký pohyb.

Za Brno bych si přál v redakčním výboru Dr. Weyra a sebe jako referenta.“33

Anketa však neučinila tak jasné závěry, jaké si Janáček představoval. Hned 1. června 1919 Branberger obdržel dopis od JHS, ve kterém byla popsána některá jednání Hromádky s Janáčkem i jejich naprosto odlišné postoje např. ve věci vysokoškolského typu školy: „P. ř za svoji věc a také v novinové zprávě, jako svoji ji ohlásil, ale my nemůžeme naprosto souhlasiti, s jeho stanoviskem $v$ př́čině nadřazenosti konzervatoře vưči té škole a proto bude třeba celou věc vyjasniti v redakčni radě. Pokud se vědecké teorie hudby týče, nemůžeme také souhlasiti s p. řed. Janáčkem, a $i$ v té př́čině máme svoje sprostředkujicí návrhy. Mistrovské kurzy at’ se pro obě

33 Opis Leoše Janáčka Janu Branbergerovi, 26. 5. 1919, JA MZM, sign. D 1455. Citováno z: ZAHRÁDKA, Jiř́i a kolektiv (ed.). Korespondence Leoše Janáčka [online]. Brno, 2016 [cit. 15. 4. 2018]. 
konservatoře účelně rozdělí. Některé v Praze a jiné zase v Brně.“" ${ }^{34}$ Patrně krátce poté zaslala JHS na MŠNO svůj elaborát s názvem „Některé myšlenky pro jednáni o zřizeni konzervatoře

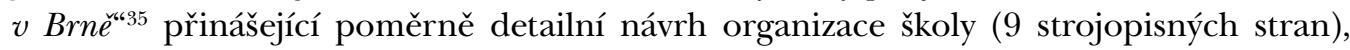
který byl v rozporu s Janáčkovou koncepcí. O něco později 22. června zaslal Branbergerovi vlastní návrh organizace nové školy ${ }^{36}$ také FSBB. Podle něj měla mít škola tři stupně: vysokoškolskou akademii, vyšší školu hudební a školu elementární. I tento návrh se v mnohém míjí s Janáčkovou vizí. Při srovnání všech tří koncepcí je zřejmé, že každý předkladatel připravoval vlastní materiál bez konzultace s ostatními.

V průběhu června 1919 byly učiněny další kroky k samotnému ustanovení brněnské konzervatoře. Jan Branberger uveřejnil článek Organisace českého hudebního života, kde představil celou organizaci a institucionalizaci hudebního dění v novém státě, včetně uspořádání hudebního školství. Zde již oznámil brzké zřízení konzervatoře hudby v Brně, ale po vzoru Prahy jako střední školy s mistrovskými kursy typu vysokoškolského. ${ }^{37}$ Krátce nato, 17. června, se uskutečnila na ministerstvu školství meziministerská porada o problematice konzervatoří v Praze a Brně. ${ }^{38}$ Janáček dostal kýženou zprávu prostřednictvím Weyra 23. června: „Zř́izeni státní konservatoře v Brněv přištím zimním semestru je úplně zajištěno. Byl Jste nesprávně informován a i informace p. $D^{r}$ Branbergera byly chybné. V rozpočtu je výslovně položka 200,000 K na zř́zeni konservatoře v Brně a sice plati tento obnos do konce tohoto roku. Konferoval jsem v té věci právě podobněs p. státním tajemnikem Drtinou a sekčním šéfem Kvapilem a zítra budeme jednati ještě s Branbergerem. Musi se stanoviti co nejdří postup při zř́zení. Rašín má pro budoucnost jisté plány, jak zapráhnout též uměni milovné kruhy do této záležitosti, jimž nyni oponovat bylo by surchovaně netaktické. Rovněž netaktické by bylo dělati nyni, kdy věc tak kvapi, nějaké experimenty s novými typy konservatoře. Na to je času dost až později. "39 Jak vidno, Janáček musel kvůli všeobecnému tlaku na rychlé zřízení školy ze svých požadavků na svébytný vysokoškolský ráz konzervatoře na chvíli slevit. Ministr Gustav Habrman pověřil referenta hudebního oddělení dr. Branbergera, aby navštívil Brno a domluvil vše potřebné, především poměr mezi hudební školou FSBB, varhanickou školou JZCHM a JHS. Branberger se během svého čtyřdenního brněnského pobytu od 30. června do 2. července nejprve setkal s představiteli JZCHM a FSBB, ale na programu měl také jednání s německými hudebními institucemi. Po dlouhé debatě ministerstvo nabídlo dosavadním zřizovatelům hudebních škol účast v kuratoriu konzervatoře, které mělo řídit ekonomické otázky. Další den navštívil Branberger manifestační schůzi JHS za přítomnosti zástupců hudebních škol z Moravy, kde

34 Dopis Antonína Hromádka Janu Branbergerovi, nedat., NA, zn. MŠ, fond Ministerstvo školství, Praha, kart. 3410, inv. č. 330 Brno.

35 Strojopisný text „Některé myšlenky pro jednání o zř́izení konzervatoře v Brně“, NA, zn. MŠ, fond Ministerstvo školství, Praha, kart. 3410, inv. č. 330 Brno.

36 Materiál Filharmonického spolku Beseda brněnská, NA, zn. MŠ, fond Ministerstvo školství, Praha, kart. 3410, inv. č. 330 Brno.

37 BRANBERGER, Jan. Organisace českého hudebního života. Lidové noviny, roč. 27, č. 177 (7. 6. 1919$)$, s. 1.

38 KUNC, op. cit. s. 4. Dopis Františka Weyra Leoši Janáčkovi, 16. 6. 1919, JA MZM, sign. D 1472. Citováno z: ZAHRÁDKA, Jiří a kolektiv (ed.). Korespondence Leoše Janáčka [online]. Brno, 2016 [cit. 15. 4. 2018].

39 Dopis Františka Weyra Leoši Janáčkovi, 23. 6. 1919, JA MZM, sign. B 2293. Citováno z: ZAHRÁDKA, Jiří a kolektiv (ed.). Korespondence Leoše Janáčka [online]. Brno, 2016 [cit. 15. 4. 2018]. 
se hovořilo o založení konzervatoře i platových a stavovských podmínkách učitelů. Následně byl př́itomen na konferenci učitelského sboru hudební školy FSBB, kde dohodnul a zajistil personálie všech učitelů školy, kteří od nového školního roku měli přejít na konzervatoř. Totéž provedl o dvě hodiny později na schůzi pedagogů varhanické školy. Poté dlouho do večerních hodin diskutoval s Janáčkem. Další den pak proběhla schůzka s představiteli hudební školy Vesny, která se právě rozpouštěla, a někteří z učitelů také žádali o přijetí na konzervatoř. Setkání se sekčním šéfem Moravského místodržitelství Dr. Černým mělo na programu zajištění a rekvírování prostor pro novou konzervatoř. Následovala schůzka $\mathrm{s}$ ředitelem Vesny Františkem Marešem ohledně předání klavírů nově vznikající škole a setkání s ředitelem brněnského Národního divadla Václavem Štechem kvůli umožnění zaměstnancům divadla vyučovat na konzervatoři. ${ }^{40}$

Vzápětí po Branbergerově vyjednávacím brněnském maratonu vypracovaly 2. července 1919 zainteresované brněnské spolky pro MŠNO společné prohlášení, ve kterém specifikovaly jednotlivé body dohody o budoucím soužití pod společnou hlavičkou, jak se na něm dohodli s Branbergerem. Oba spolky (JZCHM za varhanickou školu a FSBB) byly ochotny spolu působit na nově zřízené konzervatoři v Brně za podmínek, že MŠNO jmenuje kuratorium a profesorský sbor konzervatoře. V sedmičlenném kuratoriu zastupujícím konzervatoř jako právnickou osobu měly být zastoupeni po dvou členech představitelé obou dotčených spolků a tři zástupci včetně voleného předsedy z okruhu brněnských osobností, nikoliv však profesionálních hudebníků. Toto kuratorium mělo řídit záležitosti ekonomické, zatímco pedagogické záležitosti měl vést profesorský sbor v čele se zvoleným rektorem. Dále bylo dohodnuto, že oba spolky bezplatně poskytnou konzervatoři svůj movitý i nemovitý majetek dle předcházející úmluvy. Tedy JZCHM budovu varhanické školy na Kounicově ulici, včetně archivu, nástrojového vybavení (4 varhany, 3 klavíry atd.) a dále pak dům v zahradě školy pro bezplatné užívání ředitelem Leošem Janáčkem. Stát však musí převzít doplacení hypotečního dluhu, který JZCHM za budovu nestačila splatit. Objekt varhanické školy může konzervatoř užívat, dokud nebude postavena budova nová. FSBB dává k dispozici svůj notový archiv, knihovnu a nástroje. ${ }^{41}$ Stát musí dále zaručit poskytování trvalé roční subvence nejméně 200000 Kč. Další podmínkou byl př́ílib, že MŠNO vyzve úřední cestou zemskou politickou správu v Brně k vyhledání dalších prostor pro konzervatoř.

Pro potřeby nové školy však bylo nutné také rozšířit pedagogický sbor. Vedle učitelů přecházejících z původních hudebních škol bylo třeba zajistit nové kvalitní pedagogy, především pro mistrovské třídy. Janáček se pokusil získat Jana Kubelíka a Otakara Ševčíka pro mistrovskou třídu hry na housle, ale bez úspěchu (proto také nebylo schváleno její zřízení). ${ }^{42}$ Naopak se podařilo pro Brno získat vynikajícího klavíristu a pedagoga Viléma Kurze.

40 Zápis z Branbergerovy cesty do Brna, NA, zn. MŠ, fond Ministerstvo školství, Praha, kart. 3410, inv. č. 330 Brno.

41 Průklep prohlášení, JA MZM, sign. V 774. Originál, NA, zn. MŠ, fond Ministerstvo školství, Praha, inv. č. 3410, sign. 330 Brno.

42 Dopisy Leoše Janáčka Janu Kuncovi, 11. 7. 1919, Jana Kubelíka Leoši Janáčkovi, 3. 8. 1919, Otakara Ševčíka Leoši Janáčkovi, 7. 7. 1919, JA MZM, sign. B 2202, A 775, A 856. Citováno z: ZAHRÁDKA, Jiř́ a kolektiv (ed.): Korespondence Leoše Janácka [online]. Brno, 2016 [cit. 15. 4. 2018]. 
Pro Janáčka bylo zřízení státní konzervatoře v Brně vyvrcholením jeho životních pedagogických i organizačních snah, jak vysvítá z dopisu bratru Karlovi z 28. srpna 1919: „Dospivám vrcholu své životni práce. Varhanická škola přeměňnje se na Konservatoř státní. Budu jmenován profesorem skladby na mistrovské škole, no, a snad mne zvoli za rektora konservatoře pro rok 1919-20." ${ }^{\text {"3 }}$

Pověřený pracovník pro přípravné práce zř́zení konzervatoře Jan Kunc zaslal 5. září MŠNO vypracovaný statut konzervatoře ke schválení. Jelikož však mezitím začal školní rok, muselo MŠNO 9. září jmenovat prozatímní komitét, aby škole mohla být poskytnuta okamžitá subvence a mohla tak začít vykonávat pedagogickou činnost. ${ }^{44}$ Formální potvrzení na sebe nenechalo dlouho čekat: „Na základě ministerské rady ze dne 18. zár̆ povoluje se zř́diti v Brně konzervatoř hudby jako ústav soukromý státem subvencovaný." 45 Janáček chtěl ještě proces schválení konzervatoře jako ústavu soukromého na poslední chvíli zvrátit tím, že zaslal 21. záŕí přímo ministerskému předsedovi Vlastimilu Tusarovi telegram: „Slovutný pane! Prosíme, račte se ihned zasaditi o zestátněni brněnské konservatoře zároveň s pražskou. Stát dává na ni ročně 200000 K subvence a ministerstvo jmenuje profesory, poněvadž subvence nebude letos ani přšstího roku prekeročena. Neni př́čciny, proč brněnskou nesestátnit. Bylo by nejuětši nespravedlnosti odstrkováni Moravy, kdyby se tak stalo. " vyhýbavá odpověd’ přišla o tři dny později: „K Vašemu telegramu ze dne 21. tm sděluji, že otázka zestátněni konservatoři vưbec nebyla ještě konečně rozhodnuta. Sdělil jsem proto Vaše práni věcně priślušnému ministerstvu školstvi a národni osvěty. " J77 Janáčkovi muselo být jasné, že první část boje byla vítězná jen z části. Brno mělo sice konzervatoř, ale zatím pouze soukromou s př́ílibem, že k zestátnění dojde, pokud se škola osvědčí po ekonomické a odborné stránce. Navíc Janáček musel v této fázi rezignovat na svou vizi konzervatoře jako jednotného hudebně-vědeckého vysokoškolského ústavu. U přiležitosti zahájení činnosti konzervatoře uveřejnil $\mathrm{v}$ Lidových novinách fejeton s názvem Úvodni slovo $k$ otevřeni konservatoře hudby v Brnĕ..$^{48}$

Kvưli provizornímu statutu soukromé školy navíc padly i vyhlídky na získání dalších prostor pro fungování konzervatoře. Od počátku bylo jasné, že budova varhanické školy pro novou nesrovnatelně větší školu nebude stačit. Janáček v této souvislosti upozornil na možné využití minoritského kláštera: „Vyhledána mistnost konservatoři ještě potřebna. $S$ obtižemi při tom nebudu Vás unavovat. Je to jedna z kvadratur kläštera minoritského. Bude třeba $i$ zednických prací při úpravě a - dostat jídelnu di̊stojnickou z refektáře ven. " ${ }^{49}$ Komise

43 Dopis Leoše Janáčka Karlu Janáčkovi, 28. 8. 1919, JA MZM, sign. D 1259. Citováno z: ZAHRÁDKA, Jiř́i a kolektiv (ed.). Korespondence Leoše Janácka [online]. Brno, 2016 [cit. 15. 4. 2018].

44 Zápis agendy, NA, zn. MŠ, fond Ministerstvo školství, Praha, kart. 3410, inv. č. 330 Brno.

45 Ibid.

46 Opis telegramu Leoše Janáčka Vlastimilu Tusarovi, 21. 9. 1919, NA, zn. MŠ, fond Ministerstvo školství, Praha, kart. 3410, inv. č. 330 Brno.

47 Dopis Vlastimila Tusara Leoši Janáčkovi, 24. 11. 1919, JA MZM, sign. B 2296. Citováno z: ZAHRÁDKA, Jiř́i a kolektiv (ed.). Korespondence Leoše Janáčka [online]. Brno, 2016 [cit. 15. 4. 2018].

48 JANÁČEK, Leoš. Úvodní slovo k otevření konzervatoře v Brně. Lidové noviny, roč. 27, č. 278 (7. 10. 1919), s. 1 .

49 Dopis Leoše Janáčka Janu Branbergerovi, 7. 8. 1919, JA MZM, sign. B 1457. Citováno z: ZAHRÁDKA, Jiří a kolektiv (ed.). Korespondence Leoše Janáčka [online]. Brno, 2016 [cit. 15. 4. 2018]. 
ve složení stavebního rady Metzenauera, místodržitelského komisaře Dr. Chytila a Janáčka požádala MŠNO o pomoc při vyjednávání s Ministerstvem národní obrany, protože v dotčených prostorách sídlila vojenská jednotka. Ministr školství Habrman požádal Ministerstvo národní obrany, aby vojenské velitelství učinilo kroky pro přestěhování mužstva do novoměstských kasáren. ${ }^{50}$ Místní šetření bylo svoláno na 13 . záŕíi. ${ }^{51}$ Místnosti v minoritském klášteře nakonec, i přes protest představenstva kláštera, byly konzervatoři rozhodnutím Moravského místodržitelství z 25. září dány k užívání na dobu dvou let. ${ }^{52}$ Nakonec však z toho kroku sešlo. Janáček sdělil 22. října MŠNO, že dle vyjádření Ministerstva národní obrany je žádost o přidělení místností kvůli soukromému rázu konzervatoře bezpředmětná, jelikož zabírat kláštery mohly jen státní instituce. ${ }^{53}$

Zatím byli do kuratoria jmenováni a ministerstvem schváleni Dr. František Weyr, P. František Šup, Dr. Felix Rudiš, prof. Alois Bouda, prof. Robert Saska, František Mareš a Josef Kolbinger. Reditelem (rektorem) školy byl jmenován Leoš Janáček. Tajemníkem byl ustanoven Jan Kunc, úředníky se stali Osvald Chlubna a Jan Havlíček. Poradní sbor rektora tvořili Vilém Kurz, Max Koblížek, Jan Kunc, Jaroslav Kvapil, Rudolf Reissig a Eduard Tregler. Konzervatoř byla rozdělena na mistrovskou školu (vysoká škola), konzervatoř (střední škola) a na všeobecnou hudební školu (př́íprava na konzervatoř). Pro výuku na mistrovské škole byli jmenováni dva profesoři: Leoš Janáček (skladba) a Vilém Kurz (klavír). Profesory konzervatoře byli jmenováni Bohumil Holub (varhany a jiné předměty), Max Koblížek (teoretické předměty a intonace), Jan Kunc (skladba, harmonie, kontrapunkt, formy a instrumentace), Jaroslav Kvapil (klavír, teoretické předměty), Ladislav Malý (housle), Vilém Petrželka (obligátní klavír, teoretické předměty, hra z partitur), Rudolf Reissig (housle a komorní hra), Eduard Tregler (varhany), Ludmila Tučková (klavír, harfa). Docenti byli: Antonín Hromádka (církevní zpěv a církevní sborový zpěv), Jan Kakš (dějiny hudby), František Neumann (dirigování a řízení orchestru), Josef Sumec (akustika), Ferdinand Vach (sborový zpěv), P. Albín Zelníček (liturgika); lektoři Gracian Černušák (všeobecné dějiny), Jiří Mahen (česká literatura), Dr. Bohuslav Markalous (dějiny výtvarného umění), J. Šústal (pedagogika); výpomocní učitelé: Václav Bech (kontrabas), Josef Bok (flétna), František Bříza (fagot), Marie Dvořáková (klavír), Oskar Chlubna (teoretické předměty a nauka o nástrojích), František Jánský (lesní roh), Stanislav Krtička (klarinet), Jaroslav Kulhánek (pozoun) a Matěj Wagner (hoboj); hlavní učitelé všeobecné hudební školy: Marie Fialová (sólový zpěv), Anna Holubová (klavír), Zdenka Illnerová (klavír), Emil Šárka (klavír), Ludmila Perglerová (housle a klavír); výpomocní učitelé všeobecné hudební školy: Ludmila Šípková (klavír), Anna Dolejšová (sólový zpěv), František Krejzl (housle),

50 Úřední záznam žádosti je uložen v NA, zn. MŠ, fond Ministerstvo školství, Praha, kart. 3410, inv. č. 330 Brno.

51 Dopis Moravského místodržitelství Leoši Janáčkovi, 11. 9. 1919, JA MZM, sign. B 2295. Citováno z: ZAHRÁDKA, Jiř́i a kolektiv (ed.). Korespondence Leoše Janácka [online]. Brno, 2016 [cit. 15. 4. 2018].

52 Dopis Moravského místodržitelství Leoši Janáčkovi, 25. 9. 1919, JA MZM, sign. D 1474. Citováno z: ZAHRÁDKA, Jiří a kolektiv (ed.). Korespondence Leoše Janácka [online]. Brno, 2016 [cit. 15. 4. 2018].

53 Dopis Leoše Janáčka a Jana Kunce MŠNO, 22. 10. 1919, NA, zn. MŠ, fond Ministerstvo školství, Praha, kart. 3410, inv. č. 330 Brno. Viz též dopis Jednoty na zvelebení církevní hudby MŠNO, 31. 10. 1919, tamtéž a dopis Konzervatoře hudby MŠNO, 8. 11. 1919, tamtéž. 
František Rasch (violoncello). Během roku ještě došlo k různým změnám. Marie Dvořáková místo nepřijala a dodatečně byli ministerstvem schváleni další pedagogové: profesoři Olga Tomášová (klavír), Růžena Kurzová (klavír), Teodor Žalud (zpěv), František Kudláček (housle), Oldřich Vávra (housle); docentem byl jmenován Osvald Chlubna, lektory pak Rudolf Pelíšek místo J. Šústala, Dr. Alois Gregor (čeština), E. Billeaudeau (francouzština), E. Zelinková (italština). Výpomocní učitelé pak byli Karel Horký (trubka), Josef Karas (violoncello), na všeobecnou hudební školu byla přijata Jindřiška Rohlíková (klavír), Kamila Vaňurová (klavír), Josef Burget (housle) a Jaroslav Jahelka (housle). Písařkou a sekretářkou se stala Marie Trkanová. Celkem měl učitelský sbor téměř 60 členů. Janáčkovi se podařilo získat vynikající pedagogy, z nichž někteří předtím působili v zahraničí. Povinnost výuky měly i přední osobnosti nově ustanoveného brněnského Národního divadla. V ř́íjnu 1919 znovu požádala konzervatoř MŠNO o zř́zení mistrovské školy pro obor hra na housle a jmenování Jaroslava Kociána jejím profesorem, ${ }^{54}$ ale k jmenování nedošlo. V lednu 1920 pak byla otevřena dvouletá dramatická škola, které se pedagogicky ujali Ema Pechová, Vladimír Marek, Václav Štech a Jiří Mahen.

Zápis na konzervatoř, mistrovskou školu i všeobecnou školu se konal od 1. do 5. ř́ijna 1919, mistrovská škola měla ještě 6 . ř́jna přijímací zkoušky. Provoz konzervatoře byl slavnostně zahájen v sobotu 25. ̌ríjna 1919 v 11 hodin v budově na Kounicově ulici. ${ }^{55}$ Celkem se přihlásilo na konzervatoř 225 žáků, na kompoziční mistrovskou školu 5 a na mistrovskou školu klavírní 3 posluchači. Na všeobecnou hudební školu se přihlásilo 388 žáků, jejich počet vzrostl v druhém pololetí na $435 .{ }^{56}$ Prvními posluchači byli např. Zdeněk Chalabala, Karel Vetterl, Máša Fleischerová, Hugo a Pavel Haasovi, Břetislav Bakala či Rudolf Firkušný. Kvưli velkému počtu žáků se vyučovalo kromě hlavní budovy bývalé varhanické školy také v Besedním domě, v divadle Reduta a dalších městských školních budovách na ulici Veveří, Kounicově ulici, U solnice a v místnostech Obchodní akademie. ${ }^{57}$ Organizačně se škola podobala konzervatoři pražské; instrumentální oddělení mělo sedm ročníků (pouze dechové oddělení a obor kontrabasu měl 6 ročníků), pěvecké oddělení bylo pětileté, varhanní a skladatelsko-dirigentské čtyřleté, učitelský obor tř́letý. V listopadu byl založen žákovský sbor, krátce nato také orchestr. První veřejné vystoupení posluchačů se konalo 18. prosince 1919 na prvním domácím žákovském večeru. Janáček si zapsal u této př́ležitosti několik poznámek, snad k úvodnímu slovu: „1. Dokument školský - pruni výsledek práce! At je ode dne ke dni dokonalejši! Jste v něm zapsáni - budete vzpomináni! Uchovejte si svoje. 2. Prvé osvědčováni se - žáky - konservatoře. Co na něm závisi? Dobré jméno - visechna budoucnost. 3. Přestávka př́lišna." "58

54 Dopis Leoše Janáčka, Františka Weyra a Jana Kunce MŠNO, 15. 10. 1919 je uveřejněn In ŠTĚDROŇ, Bohumír. K počátkům brněnské konzervatoře. Opus musicum, roč. 4, 1974, s. 324.

55 ANONYM: Konservatoř hudby v Brně. Lidové noviny, roč. 27, č. 270 (29. 9. 1919), s. 3.

56 KUNDERA, Ludvík. Soukromá konservatoř (1919/1920). In Brněnská konservatoř 1919-1945. Brno: Ředitelství státní hudební a dramatické konservatoře v Brně, 1947, s. 15.

57 KUNC, op. cit. s. 6.

58 Janáčkův zápisek na koncertním programu, JA MZM, sign. (staré sb. fondy) K 6. 
Značné rozpaky vyvolala v brněnských kruzích zpráva o zestátnění pražské konzervatoře. Návrh byl sepsán poslanci 29. října 1919 (Tisk 1756$)^{59}$ a byl předložen NSČ 5 . listopadu. ${ }^{60}$ Poslanci vyzvali kulturní výbor a MŠNO, aby byl připraven příslušný zákon. MŠNO obratem zaslalo vypracovaný zákon kulturnímu výboru, který jej formuloval pro NSČ (Tisk 1907). ${ }^{61}$ Zákon byl předložen NSČ na 94. schůzi konané 4. prosince 1919, přičemž byl projednán a schválen ve zkráceném čtení, a současně byla schválena také rezoluce Františka Weyra, která požadovala projednání otázky zestátnění brněnské konservatoře v co nejkratším termínu. ${ }^{62}$ Weyr, který byl pochopitelně dobře informován o blížícím se zestátnění pražské konzervatoře, zaslal již 8 . listopadu MŠNO jménem kuratoria brněnské konzervatoře dopis, v němž do detailu vysvětloval potíže se soukromým statutem školy. ${ }^{63}$ Zestátnění pouze jedné z konzervatoří vyvolalo v Brně značnou nevoli a zároveň velký tlak na MŠNO i NSČ, aby byla co nejdřive zestátněna i brněnská konzervatoř. Kromě toho MŠNO uveřejnilo 10. prosince 1919 výnos, ve kterém byla upravena subvence brněnské soukromé konzervatoři zároveň s doporučením maximální úspornosti a poznámkou: „[...], že ústav byl zř́zzen prozatímně na rok, na zkoušku, až jak se osvědči. "64 Není divu, že takový postoj představoval poslední kapku brněnské zdrženlivosti, nebot nově zřízená konzervatoř měla na počátku subvenci $200000 \mathrm{~K}$ s tím, že musela vybudovat všechno od základu, zatímco pražská konzervatoř ač zhruba s dvojnásobným počtem posluchaču (resp. počtem posluchačů samotné konzervatoře, spolu s elementární školou měla brněnská konzervatoř posluchačů stejně) a s již vybudovaným zázemím měla po zestátnění dostat navýšený státní příspěvek 900000 K. ${ }^{65}$ Moravští poslanci proto svolali na 17. prosince 1919 schůzi, na které se usnesli: „1. Podati návrh v Národním shromáždèni na sestátněni hudebni konservatoře od $r$. 1920/21. 2. Domáhati se zveřejněni školy této (právo veřejnosti) již pro r. 1919/20. 3. Domáhati se náležitého finančního zajištěni školy již pro dobu nyneеjšiı. "66 Následně byl Jaroslavem Budinským, Františkem Weyrem a dalšími poslanci vypracován Tisk č. 2124 s datem 7. ledna 1920 obsahující návrh zestátnění ústavu: „Sestátněni konservatoře pražské a ponecháni konservatore brněnské ústavem soukromým na zkoušku na rok s ponižujici podminkou, osvědčili se, chová v sobě všechny zkázonosné důsledky, jež ohrožuji trvání brněnského ústavu mërou nejvyšš́ a ve všech směrech jeho vývoje, jelikož nestejné podminky jak na straně profesorského sboru a vybaveni ústavu, tak na straně posluchaču znemožni naprosto jakoukoli umèleckou soutěz̆, a musi dříve či pozdĕji vésti $k$ jeho zániku nebo nedưstojnému živořeni. Podepsani moravšti poslanci proto navrhuji: Národni shromáždèni račiž se usnésti, aby brněnská konservatoř byla počátkem studijního roku 1920/21 sestátněna ${ }^{67}$

59 Tisk č. 1756: https://www.psp.cz/eknih/1918ns/ps/tisky/t1756_00.htm (cit. 15. 4. 2018)

60 Tisk č. 1907: https://www.psp.cz/eknih/1918ns/ps/tisky/t1907_00.htm (cit. 15. 4. 2018)

61 Tisk č. 1907, NA, zn. MŠ, fond Ministerstvo školství, Praha, kart. 3410, inv. č. 330 Brno.

62 Opis stenografického zápisu: http://www.psp.cz/eknih/1918ns/ps/stenprot/094schuz/s094001.htm (cit. 15. 4. 2018)

63 Dopis Františka Weyra MŠNO, 8. 11. 1919, NA, zn. MŠ, fond Ministerstvo školství, Praha, kart. 3410, inv. č. 330 Brno.

64 Zápis agendy, NA, zn. MŠ, fond Ministerstvo školství, Praha, kart. 3410, inv. č. 330 Brno.

65 Opis stenografického zápisu: www.psp.cz/eknih/1918ns/ps/stenprot/094schuz/s094002.htm (cit. 15. 4. 2018)

66 Zápis agendy, NA, zn. MŠ, fond Ministerstvo školství, Praha, kart. 3410, inv. č. 330 Brno.

67 Tisk č. 2124: http://www.psp.cz/eknih/1918ns/ps/tisky/T2124_00.htm (cit. 15. 4. 2018) 
Tento tisk byl 12. ledna spolu s dalšími dvěma požadavky zaslán MŠNO. ${ }^{68}$ Přidala se také samotná konzervatoř v čele s Leošem Janáčkem, která zaslala MŠNO memorandum popisující těžkosti spojené se statutem soukromé školy, tedy nedostatek prostoru pro vyučování, odchod učitelských sil, upozadění vůči konzervatoři pražské a to v otázce oborů i finančního zabezpečení atd. ${ }^{69}$ Také vládní komisař zemského hlavního města Brna Petr Kerndlmayer v přípisu z 8. ledna žádal o zestátnění konzervatoře a to jako ústavu vysokoškolského (patrně na Janáčkovu žádost). ${ }^{70}$ Budínského a Weyrův návrh se dostal na pořad 106. schůze NSČ 16. ledna 1920, kde předsednictvo sněmovny okamžitě zadalo kulturnímu a finančnímu výboru učinit kroky k zestátnění brněnské konzervatoře. ${ }^{71}$ Na základě těchto skutečností připravil hudební referent MŠNO Jan Branberger Votum. Krátce předtím dostal 21. 1. 1920 z Brna telegram, v němž jej neurčený pisatel upozornil, že poslanci zvednou ruku pouze pro jednotnou mistrovskou školu. ${ }^{72}$ Není jasné, zda tím myslel jednotnou mistrovskou školu pro Prahu i Brno či pouze jednu mistrovskou školu v Praze. Branberger ve svém Votum z 27. února navrhuje zestátnění konzervatoře s tím, že brněnští profesoři mistrovské školy budou působit v Brně pod statutem pražské konzervatoře. Tímto opatřením by bylo de facto ustanoveno, že v Československé republice může být zřízena pouze jedna vysoká hudební škola a to v Praze. Oba brněnští profesoři (Janáček a Kurz) tak měli fakticky zůstat v Brně, ale jako exponenti pražské mistrovské školy. Zestátněna by pak byla pouze střední škola konzervatoře, jako samostatný ústav. Elementární školu Branberger rovněž doporučil k zestátnění jako cvičnou školu s omezeným počtem žáků, ale $\mathrm{s}$ učiteli měl být uzavřen smluvní poměr tak, aby mohla být škola v budoucnu zrušena. ${ }^{73}$ Svůj podpis pod Votum připojil i ministr Gustav Habrman. Mezi tím 4. února 1920 zasedal kulturní výbor NSČ, který schválil zákon o zestátnění konzervatoře od 15. záŕí $1920 .{ }^{74}$ Zpravodaj Alois Kolísek o této skutečnosti okamžitě telegramem informoval Janáčka. ${ }^{75}$ Následně jej detailně zpravil o situaci v samotném výboru i o vyhlídkách brněnské mistrovské školy: „Mistře, dik vřelý za laskavý telegram a dopis! Rozumi se, že se vynasnažime věc urychleně a co nejpř́znivěji skoncovati. Kdyby se mělo dodržeti usneseni Kult. výboru, pak bude postátnèna i mistrovská škola brněnská. Já jsem totiž $v$ dĩvodové zprávě o jednotnosti mistrovské školy vưbec nemluvil a zástupce minist. Nár. osv. také se v zasedání nezminil. Uvidíme, copak finančni výbor. Ale tam máme také své lidi. Doufejme

68 Tisk č. 2124 s požadavky NSČ, NA, zn. MŠ, fond Ministerstvo školství, Praha, kart. 3410, inv. č. 330 Brno.

69 Nedatované, Janáčkem podepsané memorandum, NA, zn. MŠ, fond Ministerstvo školství, Praha, kart. 3410, inv. č. 330 Brno. Druhý exemplár̆, JA MZM, sign. (staré sb. fondy) K 6.

70 Př́pis Petra Kerndlmayera MŠNO, 8. 1. 1920, NA, zn. MŠ, fond Ministerstvo školství, Praha, kart. 3410, inv. č. 330 Brno.

71 Opis stenografického zápisu: http://www.psp.cz/eknih/1918ns/ps/stenprot/106schuz/s106001.htm (cit. 15. 4. 2018)

72 Telegram neznámého Janu Branbergerovi, 21. 1. 1920, NA, zn. MŠ, fond Ministerstvo školství, Praha, kart. 3410 , inv. č. 330 Brno.

73 Votum z 27. 1. 1920, NA, zn. MŠ, fond Ministerstvo školství, Praha, kart. 3410, inv. č. 330 Brno.

74 Zápis ze schůze kulturního výboru ze 4. 2. 1920, APS, fond RNS, míst. 333, článek 4, kart. 12, spis. č. 400.

75 Telegram Aloise Kolíska Leoši Janáčkovi, 4. 2. 1920, JA MZM, sign. B 2308. Citováno z: ZAHRÁDKA, Jiř́ a kolektiv (ed.): Korespondence Leoše Janácka [online]. Brno 2016 [cit. 15. 4. 2018]. 
tedy, že vše štastně dopadne. ${ }^{76}$ Další dopis naznačuje, že Janáček byl velmi dobře informován o hrozícím zestátnění pouze konzervatoře jakožto střední školy. Kolísek jej dopisem z 12. února seznámil s kroky, které učinil pro to, aby byla škola zestátněna jako vysoká: „Mistře, zakročil jsem právě u ministerstva šk. a nár. osvěty. P dr. Branberger mne ujistil, že dnes věc půjde $k$ dr. Drtinovi, pozejtři k ministrovi, pak do minist. financí. Nejbližši schůze kult. výboru je v úterý. Bude-li potřebi projednáni tam, snad do té doby bude odpověd' minist. financí. $D^{r}$. Branberger mi řekl, že mu po schůzi kult. výboru 4. února ministr Habermann vytýkal, proč $v$ kult. výboru dal odhlasovati „konservatoř“ bez omezení. Odtud si vysvětlíte ten nynějš postup: ministerstvo šk. a n. osvěty dává svoje votum na postátněni konservatoř jako středni školy a na zřrizeni expositury mistrovské školy. Já jsem navrhoval „postátněni konservatoře “ bez omezeni a bez detailováni - a mi̊j návrh byl prijat kult výborem za mlčeni přitomného zástupce minist. školstvi. Dr. Branberger byl by býval $i$ pro postátněni celistvé t.j. i mistrouské školy samostatné. Ale pokyn ministerstva vyzněl jinak, totiž dle ujednáni s Vámi. Ale i tak to bude dobré. Doufám, že se ví podaři nyni vyř́dit."77 Hádankou v tomto dopise je věta, že „pokyn ministerstva vyzněl jinak, totiž dle ujednáni s Vámi“. Janáček a Kunc totiž počátkem roku 1920 jezdili velmi často do Prahy, aby tam lobovali za svou věc u poslanců, členů kulturního výboru, předsedů poslaneckých klubů i předsedy sněmovny a také na ministerstvech školství a financí. ${ }^{78}$ Je možné, že Janáček tam neprozřetelně učinil na ministerstvu školství nějaké blíže neznámé „ujednání“.

Prezidium ministerské rady zaslalo 7. února MŠNO žádost opírající se o zadání NSČ, aby v co nejkratší době vypracovalo ministerstvo z pohledu svého resortu i finanční rozvahy zprávu a návrh zákona a aby byly tyto dokumenty co nejrychleji zaslány přímo předsednictvu NSČ. Totéž mělo učinit také ministerstvo financí. ${ }^{79}$ Branberger hned 13. února vypracoval požadovanou zprávu i návrh zákona, kde v podstatě zopakoval stanoviska formulovaná před několika dny ve Votum. ${ }^{80}$ Zpráva ještě týž den putovala na ministerstvo financí. To ve svém stanovisku z 23. února zdůraznilo, že zákon musí být jednoznačný, především v tom ohledu, že v Brně bude zestátněna pouze škola střední. Obávalo se totiž pozdějších nároků na ustanovení vysoké školy i ze strany dalších subjektů. Jako problematické označilo návrh majetkových poměrů mezi státem a JZCHM týkající se především budovy bývalé varhanické školy, který měl být ze strany JZCHM přesněji formulován. ${ }^{81}$ Dále souhlasilo s omezením elementární školy pouze na komorní školu cvičnou, ale pouze jednoroční. Branberger však požadoval tříletou cvičnou školu a to také sdělil ministerstvu

76 Dopis Aloise Kolíska Leoši Janáčkovi, 7. 2. 1920, JA MZM, sign. B 390. Citováno z: ZAHRÁDKA, Jiří a kolektiv (ed.). Korespondence Leoše Janáča [online]. Brno, 2016 [cit. 15. 4. 2018].

77 Dopis Aloise Kolíska Leoši Janáčkovi, 12. 2. 1920, JA MZM, sign. B 2298. Citováno z: ZAHRÁDKA, Jiří a kolektiv (ed.). Korespondence Leoše Janáčka [online]. Brno, 2016 [cit. 15. 4. 2018].

78 KUNC, op. cit., s. 6.

79 Žádost Prezidia ministerské rady ze 7. 2. 1920, NA, zn. MŠ, fond Ministerstvo školství, Praha, kart. 3410 , inv. č. 330 Brno.

80 Zpráva a návrh zákona, NA, zn. MŠ, fond Ministerstvo školství, Praha, kart. 3410, inv. č. 330 Brno.

81 Stanovisko Ministerstva financí z 23. 2. 1920, NA, zn. MŠ, fond Ministerstvo školství, Praha, kart. 3410 , inv. č. 330 Brno. 
financí spolu s novým prohlášením JZCHM (vypracovaným Janáčkem), ${ }^{82}$ které je prakticky totožné s původní úmluvou. ${ }^{83}$ Ministerstvo financí ve svém nálezu z 3 . března nemínilo přistoupit na zestátnění tř́leté cvičné školy a navrhlo řešení (podle Branbergerova návrhu), aby škola zůstala soukromá s každoročně udělovanou státní subvencí. Navrhlo také, aby bylo s JZCHM dojednáno darování budovy konzervatoře státu a pokud nebude JZCHM souhlasit, je třeba počítat $s$ tím, že budova v každém případě nebude ze strany konzervatoře v dohledné době uvolněna. ${ }^{84}$ To také MŠNO sdělilo JZCHM a současně zažádalo o převod budovy i s inventářem do vlastnictví státu ${ }^{85}$ ale JZCHM na toto řešení nepřistoupila.

Další zasedání kulturního výboru NSČ se konalo 11. března a na programu již byl vlastní návrh na zestátnění konzervatoře a příslušný zákon. Jednalo se i o úpravě vládního návrhu na úpravu pracovních poměrů profesorů pražské konzervatoře, patrně s ohledem na jejich nové brněnské pracoviště. ${ }^{86}$

Do programu jednání NSČ se vypracovaný návrh dostal na 133. schůzi dne 22. března 1922, kde byl zařazen Tiskem č. 2592 - „Zpráva I. výboru kulturního II. výboru rozpočtového; o návrhu člena Národního Shromáždèni Dra Jar. Budinského a soudruhi̊ (tisk č. 2124), aby zestátněna byla hudebni konservator v Brně. “87 Rozsáhlá zpráva popisuje historii hudebního školství v Brně i její současnost. Poukazuje na úspěchy soukromé konzervatoře a na potřebu jejího zestátnění. Zpráva kulturního výboru z 11. března 1920 je podepsána místopředsedou Dr. Janem Herbenem a zpravodajem Dr. Aloisem Kolískem. Zpráva finančního výboru ze 17. března 1920, podepsaná předsedou R. Jarošem a zpravodajem Vladimírem Hatlákem, je nanejvýš stručná:

„Zestátnění hudební a dramatické konservatoře v Brně je důsledkem jednak resolučního usnesení Národního shromáždění, jednak také ujednání mezi ministerstvem školství a národní osvěty a ministerstvem financí.

Také důvody ušlechtilé soutěže, které vzniknou zestátněním konservatoře brněnské s konservatoří pražskou a kterouž ministerstvo školství a národní osvěty samo vítá, a okolnost, že podle výnosu téhož ministerstva č. j. 8801/1005 n. o. ze dne 13. února 1920 dostačí, pokud se týče nákladu, pro nejbližší léta částka 200.000 Kč, která je vložena již do letošního rozpočtu, tak že zestátnění dá se snadno školním rokem 1920/21 (t. j. od 1. září 1920) provésti a konečně také sdělená okolnost, že zařízení ústavu nestálo by ničeho, poněvadž konservatoř tato jako soukromý ústav je vším potřebným opatřena a budova ústavní bude při zestátnění odevzdána Jednotou k povznesení církevní hudby na Moravě bezplatně, přispívají k tomu, že konservatoř brněnská může býti zestátněna.

Rozpočtový výbor připojuje se ke zprávě kulturního výboru o zestátnění hudební a dramatické konservatoře v Brně a také k navrhovanému znění zákona.“

82 Koncept vypracovaný Leošem Janáčkem, JA MZM, sign. V 780,

83 Strojopis podepsaný předsednictvem Jednoty na zvelebení církevní hudby na Moravě, NA, zn. MŠ, fond Ministerstvo školství, Praha, kart. 3410, inv. č. 330 Brno.

84 Nález Ministerstva financí z 3. 3. 1920, NA, zn. MŠ, fond Ministerstvo školství, Praha, kart. 3410, inv. č. 330 Brno.

85 Dopis MŠNO Jednotě na zvelebení církevní hudby na Moravě, 18. 3. 1920, JA MZM, sign. V 774.

86 Zápis ze schůze kulturního výboru z 12. 3. 1920, APS, fond RNS, míst. 333, článek 4, kart. 26, spis. č. 1062.

87 Tisk č. 2124: http://www.psp.cz/eknih/1918ns/ps/tisky/T2592_00.htm (cit. 15. 4. 2018) 
Zajímavé je, JZCHM měla státu budovu konzervatoře bezplatně odevzdat, nikoliv propůjčit. K návrhu je také připojen př́íslušný zákon ve znění:

$$
\text { ze dne...........................1920, }
$$

\section{kterým se zřizuje státní hudební a dramatická konservatoř v Brně.}

Národní shromáždění republiky Československé usneslo se na tomto zákoně:

$\S 1$.

Brněnská konservatoř jest střední ústav státní s českou řečí vyučovací.

$\S 2$.

Střední škola tato jest samostatným ústavem. Práva a povinnosti, zvláště platy a jiné požitky, jakož i pense učitelů, úředníků, podúředníků a sluhů na ústavě tom zaměstnaných upravují se podle týchž zásad, podle kterých jsou upraveny pro zaměstnance střední školy zestátněné konservatoře hudby v Praze, podle zákona ze dne...

Započítání let strávených zaměstnanci brněnské státní hudební a dramatické konservatoře před jejím zestátněním do jejich postupu a pense upraveno bude ministerstvem školství a národní osvěty v dohodě s ministerstvem financí.

$\S 3$.

Státní hudební a dramatické konservatoři v Brně přiděluje se přiměřený počet profesorů mistrovské školy státní konservatoře hudby v Praze.

$\S 4$.

Provésti tento zákon ukládá se ministerstvu školství a národní osvěty v dohodě s ministerstvem financí.

$\S 5$.

Zákon tento nabývá účinnosti dnem 1. září 1920.“

Zápis projednání na samotné schůzi předkládáme pro jeho zajímavost kompletně:

„6. zpráva I. výboru kulturního, II. výboru rozpočtového o návrhu člena Národního shromáždění dra J. Budínského a soudr. (tisk č. 2124), aby sestátněna byla hudební konservatoř v Brně (tisk č. 2592).

Zpravodajové jsou občan dr. Kolísek a Hatlák. Uděluji slovo prvnímu zpravodaji, občanu dru Kolískovi.

Zpravodaj dr. Kolísek: Slavné Národní shromáždění!

Málo kdy bylo mi tak milo, ujímati se veřejně slova, jako v této chvíli před slavným sborem Národního shromáždění, kdy má se podati zpráva o zestátnění brněnské hudební konservatoře, nejprve zpráva moje - z kulturního výboru.

Tři složky hudebního uměleckého života v Brně tvoří vývoj a základ hudební konservatoře v Brně. Předně hudební a zpěvná škola fundace při klášteře starobrněnském, dále Varhanická škola, vydržovaná „Jednotou pro zvelebení církevní hudby na Moravě“, (zasloužili se o ni zvláště opat Rambousek, řed. Šulc a dr. Frant. Kolísek), konečně hudební škola spolku Filharmonická Beseda v Brně. Z první jmenované školy vyšli slavní pěvci naši Paleček a Lukes, vyšel z ní i Pavel Křížkovský, skladatel a buditel, jenž pro vývoj svérázného hudebního umění českého, byt̉ ne dle výkonnosti, ale 
jistě ideově měl právě takový význam, jako Bedřich Smetana. Druhou ze jmenovaných škol na výši uměleckou povznesl mistr Leoš Janáček, a vyšla z ní řada hudebníků nejlepších, jak výkonných, tak i skladatelů, na př. Jan Kunc. Na třetím ústavě počet žáků stále stoupal do takové výše, že bylo to jen krásným svědectvím zdatnosti této školy. A spolek Filharmonická Beseda brněnská, která onu školu vydržovala, je dobře známa svými uměleckými snahami i výkony.

Ministerská rada republiky Československé vystihla význam vyšší organisace hudebního školství v Brně a proto usnesením z 18. září 1919 zřídila v Brně hudební konservatoř, ale zatím jako ústav soukromý. Dnes, slavné Národní shromáždění, jednáme o návrhu, aby konservatoř tato byla zestátněna a to zákonem, jehož osnovu navrhuje výbor kulturní a rozpočtový.

Jako zpravodaj výboru kulturního musím si zde tak od srdce postěžovati, že návrh náš prodělával hotovou křížovou cestu. Ale podle lidového pořekadla: „Vzpomínati milo, co dřive trápilo“ - vzpomínám rád na tyto útrapy, jen když bylo jak u dotyčných ministerstev, tak i ve výboru kulturním - a za ten mluvím nejprve - docíleno, že účelnost i potřebnost zestátnění brněnské hudební konservatoře byla uznána.

Nebudu zde opakovati důvody pro zestátnění. Jsou před vámi v důvodové zprávě našeho návrhu tisk 2592. Shrnuji důvody ony v celek. Je to historický vývoj hudebního školství v Brně, žádoucí úroveň v organisaci brněnské konservatoře, již existující, ale soukromé, a její kulturní, umělecký i politický - jedná se o Brno - význam. Postátněním brněnské konservatoře hudební ukáže se vřelý zájem vlády i tohoto Národního shromáždění pro kulturní potřeby celé naší Československé republiky. Bývaly smutné zjevy, jakási nevraživost Čech a Moravy, Brna a Prahy. Říkávalo se tomu někdy moravský separatismus, ale ve skutečnosti to bylo pražské odstrkování. Doufejme, že zjevy tyto zmizí. A zestátnění brněnské hudební konservatoře jest toho př́ijemnou ukázkou i zárukou.

Pak, ráčíte-li přijati, slavné Národní shromáždění, zákon na zestátnění brněnské konservatoře hudby, země Křrižkovského a Janáčka bude míti svůj hudební ústav státní, státní ve smyslu dobroty, totiž sociální pomoci a mravní opory na prospěch kulturní úrovně společné vlasti a ke zdaru uměleckých snah jednoho národa.

Tím končím svoji zprávu a prosím, aby zpráva rozpočtového výboru byla vyslechnuta též se zájmem a pak aby zákon navrhovaný byl přijat. (Souhlas.)

Místopředseda Konečný: Za nepřítomného referenta rozpočtového výboru pana Hatláka měl převzíti referát pan Jaroš, a ten se slova vzdal.

K doslovu se přihlásil ještě p. zpravodaj. Uděluji mu slovo.

Zpravodaj posl. dr. Kolísek: V doslovu dovoluji si upozorniti na některé věci v osnově zákona. Nejprve na název tohoto ústavu.

Bylo ve výboru kulturním přijato, aby ústav tento se nazýval hudební a dramatická konservatoř v Brně. Upozorňuji, že jest to malá odchylka od názvu podobného ústavu v Praze. Ústavy jsou stejně organisovány, název jest sice jiný, ale věcně nemá to žádného rozdílu a obtíží. I pražská konservatoř byla by tento název dostala, kdyby při posledním projednávání o ni to byly dovolily formální důvody. Tolik k názvu.

Pak k $§ 3$ jenž zní:

„Státní hudební a dramatické konservatoři v Brně přiděluje se přiměřený počet profesorů mistrovské školy státní konservatoře hudby v Praze“, dovoluji si vysvětlení. Ačkoliv brněnská hudební konservatoř se k postátnění navrhuje, přece na brněnské konservatoři jako takové, tedy brněnské, postátňuje se zákonem naším jenom střední škola. Profesoři mistrovské školy, kteří na brněnské 
konservatoři působí, jsou zařazeni do svazku mistrovské školy pražské konservatoře hudby a jsou pro Brno přidělováni. Tak to bylo vyjednáno mezi ministerstvy a mezi dotyčnými interesenty. K tomuto bodu pak připojuji přání, jež se ovšem do zákona dáti nemůže, aby konservatoř pražská nepřebírala snad z nějakých „sobeckých“ - důvodů profesory z Brna ze střední školy a tak aby Brno nebylo zbavováno lepších sil. Tedy projevuji přání, aby vláda dbala toho, aby oba ústavy, jak střední škola konservatoře hudby v Praze, tak střední škola hudební a dramatické konservatoře v Brně, byly udržovány stále co do profesorstva na stejné umělecké výši. Praha má jistě přednost tím, že mistrovská škola jest jedna, totiž v Praze a přidělování do Brna se provádí jen od prrípadu k případu.

Konečně si dovoluji v doslovu říci toto: Jako jsem při pátečním jednání o pražské konservatoři, kde jsem byl zpravodajem pro zákon o úpravě služebních poměrů profesorů na pražské konservatoři, cítil v sobě jaksi Moravana a již tehdy při jednání o pražskou konservatoř jsem si vaši přízeň zjednával pro konservatoř brněnskou, o níž dnes jednáme, tak v této chvíli, když jednáme o vyšším učilišti hudebním pro hlavní město moravské, ozývá se ve mně poslanec za Slovensko a tu zase dnes projevuji prosbu a přání, aby i vláda i sněmovna, ovšem již budoucí, měly co nejvřelejší zájem o povznesení hudebního života slovenského - abych mluvil určitě, o povznesení Hudební školy v Bratislavě, aby za pomoci činitelů uměleckých Hudební škola v Bratislavě co nejdříve se vyvinula na ústav co největší a nejkrásněji řízený a aby za hmotné pomoci vlády byla přeměněna v Hudební konservatoř slovenskou.

Mám v mysli před sebou ideál, aby kdysi působily bratrsky a sestersky tyto ústavy: pražská konservatoř hudby, brněnská hudební a dramatická konservatoř a Hudební konservatoř slovenská vždy na prospěch umění a $\mathrm{k}$ ideové slávě našeho jednotného československého národa. (Výborně! Potlesk.)

Prosím, aby byl zákon navrhovaný přijat.

Místopředseda Konečný (zvoní): Prosím o zaujetí míst, přistoupíme k hlasování. (Děje se.)

Kdo souhlasí se zákonem, jeho nadpisem a úvodní formulí, jak navrhuje kulturní výbor v souhlase s výborem rozpočtovým, prosím, aby povstal. (Děje se.)

To je většina, zákon je schválen v prvním čtení.

Přeje si pan zpravodaj slova ke druhému čtení?

Zpravodaj posl. dr. Kolísek:

$\mathrm{V} \S 2$. osnovy je záhodno doplniti na konci odst. I. datum zákona, na který se zde poukazuje a který byl slavným Národním shromážděním právě v pátek usnesen. Když tato zpráva byla dávána do tisku, ještě ho nebylo. Tedy na konci odst. 1. po slovech „podle zákona ze dne“ budiž přidáno „19. března 1920“, dále číslo, které teprve v kanceláři se zjistí, a pak slova „sbírky zák. a nař.“

Pak v § 4. místo slov „ministerstvu školstvi““ a slov „s ministerstvem financí“ budiž řečeno „ministru školství“ a „ministrem financí“.

Místopředseda Konečný (zvoni): Kdo souhlasí se zákonem, právě v prvním čtení přijatým, s textovými doplňky, jak je právě pan zpravodaj přednesl a $\mathrm{k}$ přijetí doporučil, také ve druhém čtení, prosím, aby povstal. (Děje se.)

To je většina. Zákon i jeho doplňky se schvalují i ve druhém čtení a tím je tento odstavec denního pořádku vyřízen." 88

88 Přepis stenografického zápisu: http://www.psp.cz/eknih/1918ns/ps/stenprot/133schuz/s133003.htm (cit. 15. 4. 2018) 
O zařazení návrhu na program schůze NSČ Janáčka opět informoval Alois Kolísek: „Mistře, dnes jsem v kancelářich vypátral, že tisk o zestátněni Vaši konservatoř jest již hotov a bude v ponděli 22/III členưm Nár. shromážděni rozdán .... a jest již .... dán do rozvrhu pro plenárni projednáni na pondělek 22/III. Doufám pevně, že v tom pondělním rozvrhu zůstane a tak by věc byla v ponděli asi k večeru vyř́izena. Podám Vám telegrafickou zprávu. Upozorñuji, že jsem dal název Státni hudebni a dramatická konservatoř v Brně. “89 Ze stejného zdroje dostal Janáček 22. března tolik očekávanou telegrafickou zprávu: „hudebni dramaticka konservator brnenska dnes zakonem sestatnena". ${ }^{90}$ Tato zpráva měla být pro Janáčka velmi vítanou, ale byla patrně již o den dříve doplněna z jiných zdrojů o celou pravdu. Zestátněna totiž měla být pouze konzervatoř jako střední škola, zatímco mistrovská škola měla spadat pod konzervatoř v Praze. Z Janáčkovy velkoryse pojaté vize vysokoškolského ústavu nezbylo zhola nic. Janáček se to dozvěděl krátce před slavnostním koncertem konzervatoře, který se konal 21. března 1920 a byl věnován 70. výročí narození prezidenta T. G. Masaryka. Zazněla zde i premiéra Janáčkovy Balady blanické. K prvnímu provedení Balady blanické si Janáček připravil slavnostní řeč, kterou však nakonec vůbec nepřednesl a hned po premiéře skladby se beze slova vytratil. Ještě téhož dne napsal dirigentovi nastudování Františku Neumannovi: „Nemějte mi za zlé, že jsem, utekl“a ani bezprostředně se nepoděkoval Vám. I člověk se svíji, když nakapou mu do rány jedu. A to se mi stalo. Práci jste mél velkou - a nejméně oceněnou. "91 $\mathrm{O}$ dva dny později byl už Janáček se situací smířenější, jak je patrné z dopisu Kamile Stösslové: „Tak včerejším dnem, 22. březnem, je zákonitě brněnská konzervator ,pro hudebni a dramatické uměni" postátněna. Moje 39letá práce tedy zakončena. Takový ústav v našem státu něco znamená. Uvidim, jestli Brno si to dovede ocenit a vážit. Tolik lidí dostalo při tom chléb a postaveni - a jen dva z nich uznali za dobré jakžtakž dát najevo jakousi radost."92

Kuratorium dosud soukromé brněnské konzervatoře se ještě v červnu 1920 ohradilo prostřednictvím Františka Weyra proti zákonu přijatému 22. března, především v otázce jediné mistrovské školy a tím nadřazenému postavení pražské konzervatoře, a navrhovalo alespoň, aby byl trvalý počet profesorů mistrovské školy přidělen do Brna. MŠNO však této žádosti nevyhovělo a naopak zdůraznilo nezávislost profesorů mistrovské školy na brněnské konzervatoři.$^{93}$ Dne 15 . září 1920 jmenoval prezident Československé republiky Janáčka profesorem mistrovské školy v Praze a to s platností od 1. července téhož roku. ${ }^{94}$ Vláda také 5. října 1920 jmenovala Jana Kunce správcem a posléze i ředitelem státní brněnské konzervatoře. ${ }^{95}$ Tím Janáčkův vliv na chod 40 let budovaného ústavu

89 Dopis Aloise Kolíska Leoši Janáčkovi, 20. 3. 1920, JA MZM, sign. B 382. Citováno z: ZAHRÁDKA, Jiří a kolektiv (ed.). Korespondence Leoše Janáčka [online]. Brno, 2016 [cit. 15. 4. 2018].

90 Telegram Aloise Kolíska Leoši Janáčkovi, 22. 3. 1920, JA MZM, sign. B 2309. Citováno z: ZAHRÁDKA, Jiří a kolektiv (ed.). Korespondence Leoše Janáčka [online]. Brno, 2016 [cit. 15. 4. 2018].

91 Dopis Leoše Janáčka Františku Neumannovi, 21. 3. 1920, JA MZM, sign. B 1011. Citováno z: ZAHRÁDKA, Jiří a kolektiv (ed.). Korespondence Leoše Janáčka [online]. Brno, 2016 [cit. 15. 4. 2018].

92 Dopis Leoše Janáčka Kamile Stösslové, 23. 3. 1920, JA MZM, sign. E 1190. Citováno z: ZAHRÁDKA, Jiří a kolektiv (ed.). Korespondence Leoše Janáčka [online]. Brno, 2016 [cit. 15. 4. 2018].

93 Dopis Františka Weyra MŠNO, 7. 6. 1920, a rozhodnutí MŠNO, NA, zn. MŠ, fond Ministerstvo školství, Praha, kart. 3410, inv. č. 330 Brno.

94 Janáčkův spis, NA, zn. MŠ, fond Ministerstvo školství, Praha - osobní, kart. 6, inv. č. Janáček.

95 ZOUHAR, Zdeněk. Jan Kunc. Praha: SPN, 1960, s. 94. 
skončil. Už na konci školního roku 1919/20 Jan Branberger v Brně projednal rozpuštění kuratoria soukromé konzervatoře a personálie nové konzervatoře státní. Dořešeny byly také záležitosti elementární školy, která zestátněna nebyla a vrátila se tak zpátky pod křídla Filharmonického spolku Beseda brněnská jako její hudební škola.

Zamysleme se nyní, proč Janáčkova koncepce konzervatoře jako vysokoškolského hudebně-vědeckého ústavu skončila nezdarem a proč osobnost, která se tolik zasloužila o brněnské hudební školství, byla v novém státě zbavena možnosti ovlivňovat dění na brněnské konzervatoři. Pro odpověd' se musíme vrátit do roku 1918. Janáček neměl v Brně takovou pozici, jak by se dnes mohlo zdát. V brněnských českých kulturních kruzích měl již řadu let spoustu nepřátel (připomeňme alespoň ostré výpady ve výboru Družstva českého Národního divadla v Brně proti němu i jeho tvorbě). ${ }^{96}$ Janáček byl jistě ve svém městě nepřehlédnutelnou osobností, ale z nezaujatých pamětí, např. Františka Weyra, je zřejmé, že byl chápán do značné míry jako podivínský, snad i konfliktní člověk, který oplýval specifickým způsobem uvažování budícím u někoho úsměv, u někoho rozhořčení. Navíc měl mnoho odpůrců mezi svými pedagogy i bývalými žáky. Není tedy překvapením, že když se v Brně roznesla zpráva, že Janáček usiluje o založení konzervatoře, objevily se obavy, zda je právě on tou nejpovolanější osobou. To vysvítá například z dopisu Jaroslava Helferta, důležitého brněnského kulturního činitele a ředitele Moravského zemského muzea, bratrovi Vladimírovi z 8. února 1919: „Zatím ale ještě jednu věc, kterou zařid” hned a co nejdř́ve: s otázkou brněnské konzervatoře se nyni energicky hýbe; pákou je Janáček a proto mám obavy, aby ten podnik nedostal hned do vínku zárodek neduživosti. "977 Vladimír Helfert, pozdější velký propagátor Janáčkovy hudby, byl ještě v roce 1919 na druhé straně barikády. Nejedlého žák a také jeho švagr byl na straně svého učitele nejenom v př́padě vyhrocených postojů vůči Dvořákovi, Sukovi, ale také Janáčkovi. Ten si toho byl dobře vědom a udržoval si od Helferta rezervovaný odstup. Ještě v prosinci roku 1917 píše ve svém fejetonu Výlety páně Broučkovy: „V hrozném strachu před nejedlým Helfertem, nemilosrdným kritikem měsičním, vzpominám dokladů z literatury hudebni." "Vladimír Helfert se s bratrem Jaroslavem, který byl členem výboru Družstva českého Národního divadla v Brně, všemožně pokoušeli prosadit po roce 1918 na místo šéfa opery brněnského divadla Otakara Ostrčila, dalšího Nejedlého oblíbence. Navíc Vladimír Helfert brzy po převratu přesídlil do Brna a od záři 1919 se stal pedagogem na nově založené Masarykově univerzitě, kde působil jako vedoucí filozofického semináře další Nejedlého stoupenec Otakar Zich. V roce 1919 Helfert založil Hudební archiv Moravského zemského muzea a o dva roky později také Seminář pro hudební vědu na Filozofické fakultě Masarykovy univerzity. Na samém konci Branbergerovy návštěvy Brna, během které dojednával podmínky vzniku konzervatoře, napsal Jaroslav Helfert bratrovi Vladimírovi do Prahy: „Měl jsem dnes

96 ZAHRÁDKA, Jiří. „Divadlo nesmi býti lidu komedii. “ Leoš Janáček a Národni divadlo v Brně. Brno: Moravské zemské muzeum, 2012, s. 61.

97 Dopis Jaroslava Helferta Vladimíru Helfertovi, 8. 2. 1919, ODH MZM, celek Korespondence Vladimíra Helferta, sign. D 347.

98 JANÁČEK, Leoš. Výlety páně Broučkovy. Jeden do měsíce, druhá do XV. století. Lidové noviny, roč. 25, č. 351 (23. 12. 1917), s. 1 . 
velmi zajimavou rozmluvu s Janáčkem. Byl za mnou v muzeu, hned za ním přišel Branberger, Reissig, Hromádka. Upekli tyto dni konzervatoř v Brně. Jsou věci velmi závažné a bylo by dobře, abys do toho byl dopodrobna zasvěcen." ${ }^{99} \mathrm{Z}$ dopisu není jasné, zda se měl také Vladimír Helfert ucházet o (ředitelské?) místo. Krátce nato Jaroslav Helfert informoval bratra Vladimíra: „Tak např. mi Janáček řikal, že se zasazoval o povoláni Tvé na konzervatoř a bylo prej to zmařeno." 100 Jaroslav Helfert slovem „prej“ výstižně ilustruje absurdnost celé situace a to oboustrannou. Vladimír Helfert, tento veliký Janáčkův odpůrce, měl v té době určité ambice v muzeu i na nově založené univerzitě, a jistě musel být zděšen představou realizace Janáčkovy koncepce konzervatoře jako hudebního a vědeckého vysokoškolského ústavu, která by vedla k tomu, že hudební vědy by se namísto univerzity vyučovaly dle Janáčkova návrhu na konzervatoři, takže Helfert by se stal podřízeným osobnosti, proti níž léta bojoval. Není bez zajímavosti, že bezprostředně po 28. ř́ínu 1918 napsal Zdeněk Nejedlý Vladimírovi Helferovi: „Domluvili jsme se i s U. Bes. o jakousi společnou akci, podali podáni $k$ N. výboru proti Kàanovi, jednali jsme i o reformě konzervatoře - pokud možno bez ředitele vůbec. “101 Kàan byl jak známo dlouholetým ředitelem a pedagogem pražské konzervatoře. Nebyla to jediná čistka, kterou se Nejedlý rozhodl provést, připomeňme ještě alespoň pokus o diskreditaci Josefa Suka. Těžko říct, zda Nejedlým iniciované události na pražské konzervatoři inspirovaly také brněnské revolucionáře k sepsání petice proti Janáčkovi, nebo zda na tom měl osobní zájem sám Nejedlý, který měl s Janáčkem nevyřízené účty. Jde o již mnohokrát probíraný „Janáčkův případ“, na který upozornil v roce 1930 Gracian Černušák ${ }^{102}$ a následně se jím zabýval Osvald Chubna, ${ }^{103}$ Ivan Petrželka, ${ }^{104}$ John Tyrrell ${ }^{105}$ a naposledy Karel Steinmetz. ${ }^{106} \mathrm{~K}$ tomuto bodu tedy jen krátce. Šlo o to, že se Janáček počátkem roku 1919 dostal do konfliktu se dvěma učiteli, kteří následně odeslali ve spojení s JHS na MŠNO memorandum, které dle Graciana Černušáka „nenechávalo na Janáčkově ředitelské a učitelské činnosti poctivého vlasu, stavělo se odmítavě k jeho skladatelské tvorbě a končilo se požadavkem, aby s ředitelem Janáčkem bylo naloženo tak jako s ředitelem Kàanem." 107 Toto memorandum se nám nedochovalo ani v archivu MŠNO či NSČ. Dnes tedy můžeme jen uhadovat míru radikálnosti a přesný obsah tohoto prohlášení, podobně jako jména jeho autorů a signatář̉o Je také možné, že souviselo s memorandem vypracovaným pro kulturní komisi NSČ Janem Kuncem, o kterém ještě pojednáme. Podstatné je, že se memorandum nedostalo na stránky novin a tedy mezi

99 Dopis Jaroslava Helferta Vladimíru Helfertovi, 4. 7. 1919, ODH MZM, celek Korespondence Vladimíra Helferta, sign. C 60 .

100 Dopis Jaroslava Helferta Vladimíru Helfertovi, 9. 7. 1919, ODH MZM, sign. D 1259.

101 Nedatovaný dopis Zdeňka Nejedlého Vladimíru Helfertovi, ODH MZM, sign. A 1416.

102 Šifra-k (ČERNUŠÁK, Gracian). Janáčkův případ. Lidové noviny, roč. 38, spec. tisk, 26. 12. 1930, s. 2.

103 CHLUBNA, Osvald. Vzpomínky na Janáčkův př́ípad. Opus musicum, roč. 2, 1970, s. 281-283.

104 PETRŽELKA, Ivan. Vzpomínka na Janáčkův př́ípad. Opus musicum, roč. 16, 1984, s. 39-40.

105 TYRRELL, John. Janáček, Years of a Life. Volume II (1914-1928). The Lonely Blackbird. London: Faber and Faber, 2007.

106 STEINMETZ, Karel: „Janáčkův případ“ a role některých Janáčkových žáků v něm. In Karel Steinmetz Muzikologické studie. Ostrava: Ostravská univerzita, 2015, s. 86-91.

107 Viz pozn. 102. 
širokou veřejnost, protože veřejné propírání kauzy by jistě otřáslo Janáčkovou autoritou. O to také autorům prohlášení šlo, ale šéfredaktor Lidových novin Arnošt Heinrich otištění zamítl. ${ }^{108}$ Otevřeně vystoupil proti Janáčkovi jeho žák Vilém Petrželka, kterému se podařilo uveřejnit v dubnu 1919 v Hudebni revue článek Hudebni život brněnský, v němž píše: „Každý by se přirozeně tázal, což pak nežiji v Brně hudebni umělci? Žiji, ale nemaji bohužel až na p. ř ditele Varhanické školy Janáčka ni nejmenšiho vlivu na hudební život. [...] Na druhé straně ředitel Varhanické školy Janáček, známý svoji nepř́stupností a aristokratičností, nemá ani jedné nitky, která by ho spojovala s mladou produkci a reprodukci. Nedovedl si vytvorit, jak víme, nějaké kompozični školy. Jeho žáci, chtěli-li dále růst a se vyvinouti, museli bud’ do Prahy neb do ciziny. Studiem tři roků na Varhanické škole končil styk Janáčkĩv s jeho žáky, který byl také čistě školský a tak suchý, že jsme se mnohdy divili, že stoji před námi umělec jména Janáčkova. Nebyl nám o nic bližši než každý jiný středoškolský ředitel. Zaklepal-li brněnský či moravský, produktivni neb reproduktivni umělec na dvére Filharmonického spolku Besedy brněnské neb Varhanické školy, byl u oněch odbyt s diplomatickými výmluvami neb sliby u těchto tak, že mu zašla chut' na takové pokusy. Pan ředitel Janáček zapomněl, že začal v Brně též jednou jako mladý umělec a že mu tenkráte jistě veřejnost brněnská vyšla daleko více vstř́c, než on brněnské mladé generaci hudebni. Máme bohužel jak se strany p. ředitele Janáčka, tak i filharmonického spolku Besedy brněnské doklady neochoty a bezohlednosti vưči mladé produkci moravské, že je nám stydno toho vzpominati. [...] Dnes však poměry v Brně a rozhodujicí činitelé nejen dusí veškerou jejich činnost, ale celý vývin jejich individuality od kořene a začátku jejich uměleckého byti znemožňuji. Skvělým př́padem podporováni své produkce i reprodukce by mohla býti Brnu Praha. " ${ }^{109}$ Janáček o těchto akcích organizovaných proti jeho osobě věděl a velice ho to trápilo, jak vysvítá z několika dopisů Kamile Stösslové z března 1919: „Hati se mi moje plány. Derou se divni lidé do popředi a považte, podali spis ministerstvu, abych já nebyl ředitelem konservatoře v Brně! Celý život jsem věnoval té myšlence a ted' mi stroji takovou odplatu. Snad najdou se lidé, kteři zkř́ž́i jejich záměry. Ale ztrpčuje mi to mnohé chvile!"110 "Já tu mezi tím prodělal boži dopuštění. Vite, je z jisté strany boj proti mně. Proč, nevím. Vyhraji-li, též nevím. "111

Další překážkou, která mohla překazit Janáčkovy plány, byl úsudek samotného referenta MŠNO Dr. Jana Branbergera. Byl mnohaletým tajemníkem pražské konzervatoře a také pedagogem tamní mistrovské školy. Jeho velká zkušenost a znalost nejenom hudebních poměrů jej v roce 1919 přivedla na MŠNO, kde měl ze své pozice přednosty hudebního odboru zcela zásadní vliv na řešení otázek spojených s hudebním školstvím. Není překvapivé, že v případě zestátnění stranil v prvé řadě konzervatoři pražské. Nadto jistě neměl zájem na tom, vybudovat v Brně Janáčkem vysněný vysokoškolský ústav tolik odlišný od pražského učiliště, které by tímto pravděpodobně předčil. Těžko dnes pouze z úředních záznamů a kusých informací o kuloárových jednáních určit, nakolik byl Branberger osobně přesvědčený o myšlence pouze jediné vysokoškolské mistrovské

108 Ibid.

109 PETRŽELKA, Vilém. Hudební život brněnský. In Hudebni revue, roč. 12, č. sešit 7 (duben 1919), s. 281-282. 110 Dopis Leoše Janáčka Kamile Stösslové, 11. 3. 1919, JA MZM, sign. E 123. Citováno z: ZAHRÁDKA, Jiří a kolektiv (ed.). Korespondence Leoše Janáčka [online]. Brno, 2016 [cit. 15. 4. 2018].

111 Dopis Leoše Janáčka Kamile Stösslové, 20. 3. 1919, JA MZM, sign. E 126. Citováno z: ZAHRÁDKA, Jiř́i a kolektiv (ed.). Korespondence Leoše Janáčka [online]. Brno, 2016 [cit. 15. 4. 2018]. 
školy a to v Praze, nebo do jaké míry byl pouze loajální k představě ministerstva financí, které si v Brně za dané situace žádnou další vysokou školu v dohledné době nepřálo. Pravdou je, že na zřízení státní konzervatoře v Brně Branberger určitě zájem měl, ale nikoliv na zrŕzení brněnské mistrovské školy ani na realizaci vysokoškolské konzervatoře podle Janáčkovy koncepce.

Podstatnou roli v celé kauze sehrál Janáčkův žák Jan Kunc. Již od roku 1907 byl $\mathrm{s}$ Janáčkem v konfliktu, který se však časem podařilo částečně zklidnit. Sám Kunc, ač s Janáčkem neměl nejlepší vztahy, navenek jeho dílo zasvěceně propagoval. V roce 1918 nastoupil na místo korepetitora do pražského Národního divadla. S Prahou měl již dřive významněǰši styky; studoval u Vítězslava Nováka, angažoval se ve Spolku pro pěstování písně a znal se i s Branbergerem. Snad proto si jej Branberger na počátku roku 1919 vybral jako experta na posouzení otázky vzniku státní konzervatoře v Brně i její koncepce. Kunc byl patrně značně ambiciózní a tak ve své zprávě nenechal nit suchou nejenom na Janáčkovi, ale ani na dosavadním brněnském hudebním školství, včetně ústavu, který sám absolvoval, tedy varhanické škole:

„4. Pro svou málo odbornou organizaci atd. byly povinnými předměty (kromě theoretických) varhany, klavír, housle a zpěv a nepovinnými ještě nástroje dechové, nemohlo to přinésti v praktických předmětech k nějaké vynikající dokonalosti, jež jedině při specializaci studia je možna. Tím vlastně její absolventi při soutěži s jinými byli méněcennými.

5. Vedle středoškolských absolventů byli přijímáni do ní i žáci, kteří měli jen obecnou školu. Ti pak zdržovali jiné ve studiu, nechápajíce zejména theoretických nauk ředitele Janáčka (nauky o harmonizaci, rytmu, formách, nápěvcích mluvy), jež přednášel odlišně od jiných hudebních ústavů a kterým rozuměli sotva absolventi celé střední školy.

6. Tyto nauky byly velmi na závadu rozvoji školy. Nauka o harmonii na př. má sice osobitou (namnoze však nesrozumitelnou) terminologii, je snad theoreticky zajímavá a snad i poeticky psaná a přednášená, ale v praxi nevykazuje těch výsledků, jimž se mohou vykázati jiné nauky harmonie obecně užívané. Pro její tě̌̌kou nesrozumitelnost bylo potřebí věnovati jí daleko více hodin, než by bylo třeba normálně a tím mařil se čas, jehož mohlo se při užívání jiné harmonie využíti pro praktická cvičení. Nauka o rhytmu měla by snad oprávnění na vysoké škole hudební, ale jistě nemá toho praktického významu, který jí její autor přisuzuje (nebot kolik znamenitých skladatelů světa vyrostlo bez její znalosti!) Tak jako nauka o nápěvcích mluvy, zajímavé sice pro osobnost svého autora a v mnohých postř̌zích pravdu mající, pro tvoření hudební (a zejména dramatické) však málo nutná (nebot hudby rodí se také v hlavě fantasií!) Přripomenu-li, že i v nauce o formách zacházel p. ředitel Janáček do svých zvláštností a že na druhé straně neuznával běžného kontrapunktu nutě žáky k osobitým (!) násilnostem, je div že ti, kteří měli přilležitost informovat se o škole dříve, než do ní vstoupili, že odcházeli raději jinam, a že i uprostřed roku vystupovali a odcházeli. Mnozí jiní? Není charakteristické, že inspektory školy bývali laikové, kteří hudbě vůbec nerozuměli?

Jistě smutným vysvědčením prosperity školy, že za více než 30 let svého trvání nevychovala ani jednoho významného skladatele, který z jejích bývalých žáků $\mathrm{k}$ nějakému významu to přivedl, ten se tomu, co mu varh. škola nemohla dáti, vyučil jinde, bud’ v Praze nebo v cizině. Je neméně smutná skutečnost, že dnes stojí p. řed. Janáček sám, úplně osamocen, maje proti sobě namnoze své bývalé žáky a př̀ sobě 2.3 mladé lidi, kteří dále nebyli než v Brně a nic jiného nepoznali. Přec 
Janáček nepřispěl - je to trapná pravda - k rozvoji varhanické školy, ale byl příčinou, že pod ním jen živořila. [...]

Poněvadž ovšem to nebude škola vysoká, a poněvadž nebude úplná, bude potřebí někoho, kdo by se o její organisaci staral. To by mohl a měl také býti ředitel konservatoře, jemuž by však škola musila přirůst k srdci. Nebot̉ rektor od roku k roku volený školy nevybuduje a také na žádný sbor profesorský, v němž kolik hlasů, tolik smyslů, nýbrž jedinec jenž má schopnost a vůli organisační. Nebylo by ředitele, musel by býti zřízen tajemník zvlášt placený, jenž by se o organisaci školy staral. Zmiňuje se o tom, že F. B. [Filharmonický spolek Beseda Brněnská] chce přistoupiti na spojení, když p. řed. Janáček nebude ředitelem. ̌̌eklo se tedy, že se bude volit rektor - rok od roku. “112

Kuncův postoj se Branbergrovi jistě zamlouval a počítal s ním jako s důležitým hráčem v otázce personálního obsazení příští konzervatoře. Ve svých rukopisných pamětech Kunc vzpomíná, jak mu byla nabídnuta funkce tajemníka konzervatoře. Došlo k tomu během Branbergrova čtyřdenním pobytu v Brně na přelomu června a července 1919. Kunc byl tou dobou vyslán svým tehdejším šéfem Karlem Kovařovicem do Brna, aby zařídil ubytování pro Rosu Newmarch. To dojednal v hotelu Slavia a tam se náhodou připojil ke kuloárovému jednání o nové konservatoři: „Na to jsem v úterý večer o $1 / 29$. hodině přišel do kavárny Slávie, poručil si kávu a kupu novin, a když jsem je přečetl, rozhlédl jsem se asi o 1/2 11. hodině po kavárně a viděl jsem v jednom koutě všechny brněnské muzikanty a s nimi Dr. Branbergera, tehdy tajemnika ministerstva školstvi. Zvědavosti popuzen, přišel jsem $k$ nim, a tu jsem viděl, jak, dělaji" brněnskou konzervatoř. Rozdělovali si, čemu bude kdo z nich učit: Kobližek, Tregler, Hromádka a jini, Asi tak o 1/212 hodině v noci obrátil se na mne Dr. Branberger s dotazem: „A nechtěl Vy byste být tajemnikem konzervatoře?"113

Zda setkání bylo skutečně tak náhodné, se můžeme jen dohadovat, ale důležitou zprávou je, že Branberger soukromě jednal s Janáčkovými odpůrci jak z varhanické školy tak z JHS. Na Branbergerův návrh Janáček v dobré víře svého organizačně velmi schopného žáka opět přijal (na varhanické škole učil naposledy v letech 1912-13). Kunc tak patrně musel hrát dvojí hru; jednu jako oficiální Janáčkův zástupce, který musel být se svým nadřízeným v názorovém souladu, a druhou, v rámci které neoficiálně jednal s Janáčkovými odpůrci a Janem Branbergerem o středoškolském typu konzervatoře a snad i omezení Janáčkova vlivu. To dokládá Kuncův koncept nově vznikající konzervatoře někdy z přelomu let 1919/20, kde již píše o mistrovské škole jako o pobočce pražské konzervatoře a o brněnské konzervatoři jako škole střední. Z textu je zřejmé, že měl Kunc přesné informace z MŠNO i Ministerstva financí. ${ }^{114}$ Jistě ne náhodou byl Kunc ve dnech, kdy byla brněnská konzervatoř zestátněna, jmenován do poradního hudebního sboru při MŠNO. ${ }^{115}$ Kunc popisuje, že na konferenci, kde mu Branberger předal pověření, se ve svém projevu loučil s Janáčkem tak dojemně, že se skladatel rozplakal. ${ }^{116}$ Přitom hned

112 Viz pozn. 14.

113 Rukopisné paměti Jana Kunce, ODH, sign. G 6815.

114 Koncepce je vložena v zápisníku Jana Kunce, ODH, sign. G 6817.

115 ANONYM. Denní zprávy. Lidové noviny, roč. 28, č. 120 (7. 3. 1920), s. 4.

116 Viz pozn. 113. 
po svém jmenování správcem Státní hudební a dramatické konzervatoře v Brně svolal Kunc na 18. ř́jina 1920 schůzi profesorského sboru, na které zrušil výuku podle Janáčkovy Úplné nauky o harmonii a nahradil ji metodou Šínovou, která byla vyučována v Praze. At̉ už byl tento krok učiněn z jakéhokoliv důvodu, znamenal de facto konec Janáčkovy výjimečné výukové metody, kterou rozvíjel téměř 30 let. Kunc ve své vzpomínce uvádí, že Janáček pochopil důvody takového postupu: „Janáček se zamyslil, zakýval několikrát hlavou, nic na to neřekl a v dobrém mne propustil." 117 Nelze zde nepřipomenout Janáčkovu reakci na Kuncův ultimativní dopis z roku 1909, kde si červenou pastelkou připsal: „Jidás““ ${ }^{118}$ Ve skutečnosti se pokusil Kuncovo rozhodnutí alespoň částečně zvrátit. Proti zrušení výuky podle Janáčkovy metody se jednak postavila část pedagogů (Tučková, Chlubna, Kvapil), ale i samotná JZCHM. Ta poslala dopis MŠNO, v němž detailně specifikovala propůjčení svého majetku státu (tedy nikoliv bezplatné převedení, jak stálo v zákoně) a také protestovala proti odstranění Janáčkovy výukové metody s poukazem, že se podle ní na varhanické škole úspěšně vyučovalo několik desítek let, a požadovala, aby byla zachována alespoň pro varhaníky. ${ }^{119}$

Kunc se však patrně nadále obával Janáčkova vlivu a proto žádal pozměnit nařízení MŠNO, které umožňovalo profesorům mistrovské školy provádět inspekce v hodinách konzervatoře: „Je možno si predstaviti, že by prof. Janáček (podepsaný prosi za odpuštěni, že je $k$ objasněni svého minèni nucen užívati konkrétnich př̀ikladi̊) vyslovil se př́znivě o vyučováni harmonii, které se děje methodami, jež on nazývá pourchnimi a nevědeckými? Jak by přišel profesor konservatoře $k$ tomu, aby mělo být o nëm snad nepř́iznivě ministerstvu referováno proto, že je jiného uměleckého vyznáni, než-li profesor mistrovské školy, který je náhodou pověrén inspekci?" “120

Brněnská Státní hudební a dramatická konzervatoř se ubírala vlastní cestou, bez sebemenšího Janáčkova vlivu. Jistě ne náhodou se v roce 1920 ujali výuky mladých skladatelů právě Jan Kunc a Vilém Petrželka. Janáček ale nepřestal snít o své hudebně-vědecké vysoké škole. V roce 1922 u př́ležitosti pražské premiéry Káti Kabanové zaslal prostřednictvím Kanceláře prezidenta republiky pozvání T. G. Masarykovi, v němž píše: „Rád bych osobně pozval pana presidenta Dr. Masaryka a rád bych se př́ té př́ležitosti dotknul nevyjasněného poměru t. zn. mistrouských škol skladby, ku vysokoškolskému učeni. Bylo by možno, aby mne p. president príial ve středu, dne 28. listopadu? " ${ }^{121} \mathrm{~K}$ setkání však nedošlo. A tak Janáček alespoň svým studentům mistrovské školy zařídil možnost navštěvovat některé přednášky na Filozofické fakultě Masarykovy univerzity. Univerzitní profesorský sbor v dubnu 1926 rozhodl, že Janáčkovi žáci mohou navštěvovat přednášky z estetiky a pokusné

117 Kuncův rukopis s názvem „Vzpomínky na Leoše Janáčka“, ODH MZM, sine sign. (zpracovávaný fond).

118 Dopis Jana Kunce Leoši Janáčkovi, 23. 6. 1909, JA MZM, sign. A 315. Citováno z: ZAHRÁDKA, Jiří a kolektiv (ed.). Korespondence Leoše Janáčka [online]. Brno, 2016 [cit. 15. 4. 2018].

119 Opis strojopisu určeného MŠNO, JA MZM, senza sign. (zpracovávaný fond).

120 Připomínkovaný návrh nového statutu z 28. 12. 1920, NA, zn. MŠ, fond Ministerstvo školství, Praha, kart. 3410, inv. č. 330 Brno.

121 Dopis Leoše Janáčka Kanceláři prezidenta republiky, 25. 11. 1922 je uložen v Archivu Kanceláře prezidenta republiky, kopie v JA MZM, sign. D 1661. Citováno z: ZAHRÁDKA, Jiří a kolektiv (ed.). Korespondence Leoše Janáčka [online]. Brno, 2016 [cit. 15. 4. 2018]. 
psychologie. ${ }^{122}$ Zůstává otázkou, do jaké míry by byla Janáčkova koncepce hudebně-vědecké vysokoškolské instituce, postavené na jeho chápání hudební psychologie, vůbec životaschopná. Odpověd’ však už není předmětem této studie.

122 Dopis Děkanství Filozofické fakulty Masarykovy univerzity Leoši Janáčkovi, 6. 4. 1921, JA MZM, sign. (staré sb. fondy) JM 6. 


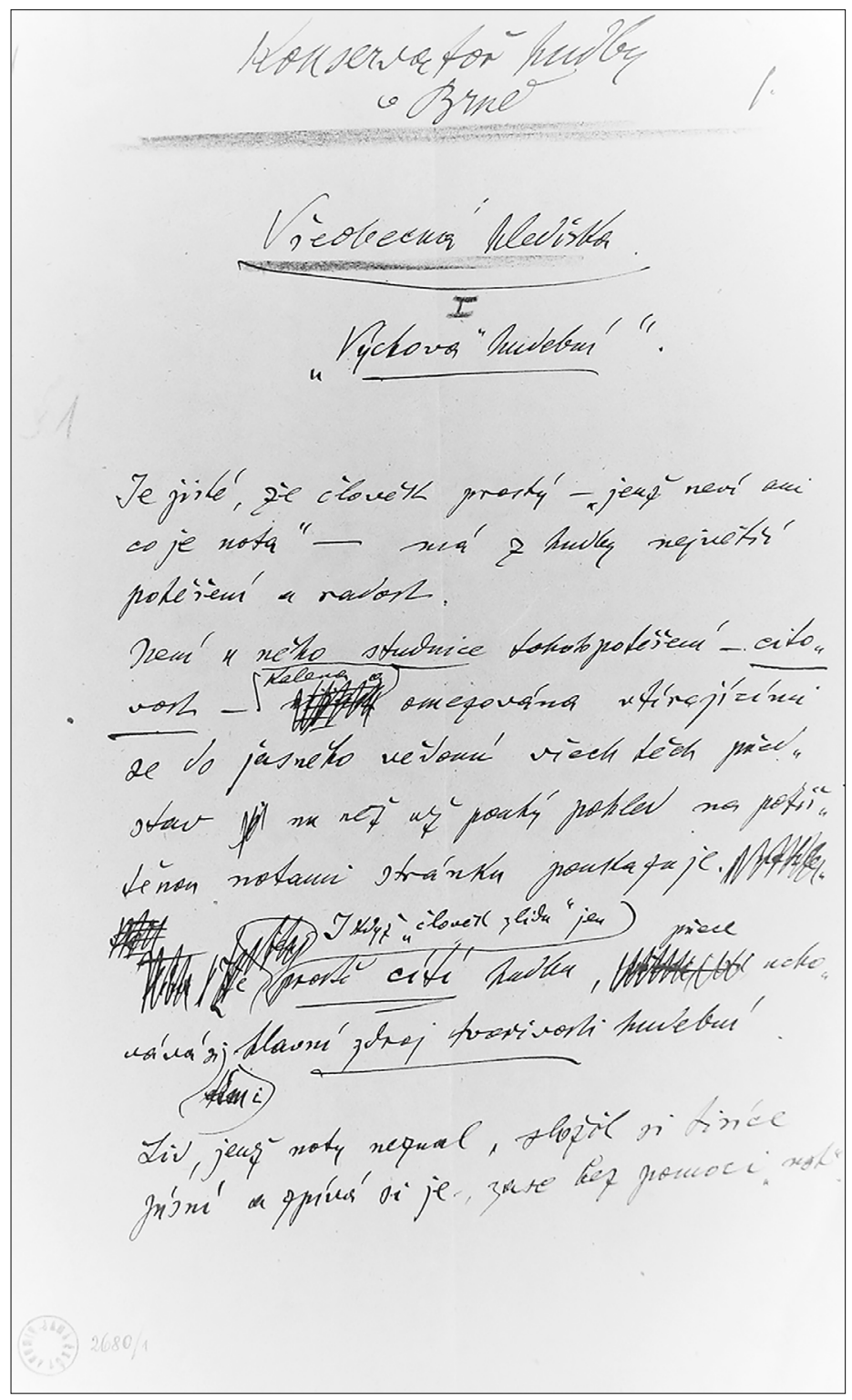

Obr. 1 Jeden z Janáčkových náčrtů koncepce brněnské konzervatoře, JA MZM, sign. $K 4$. 


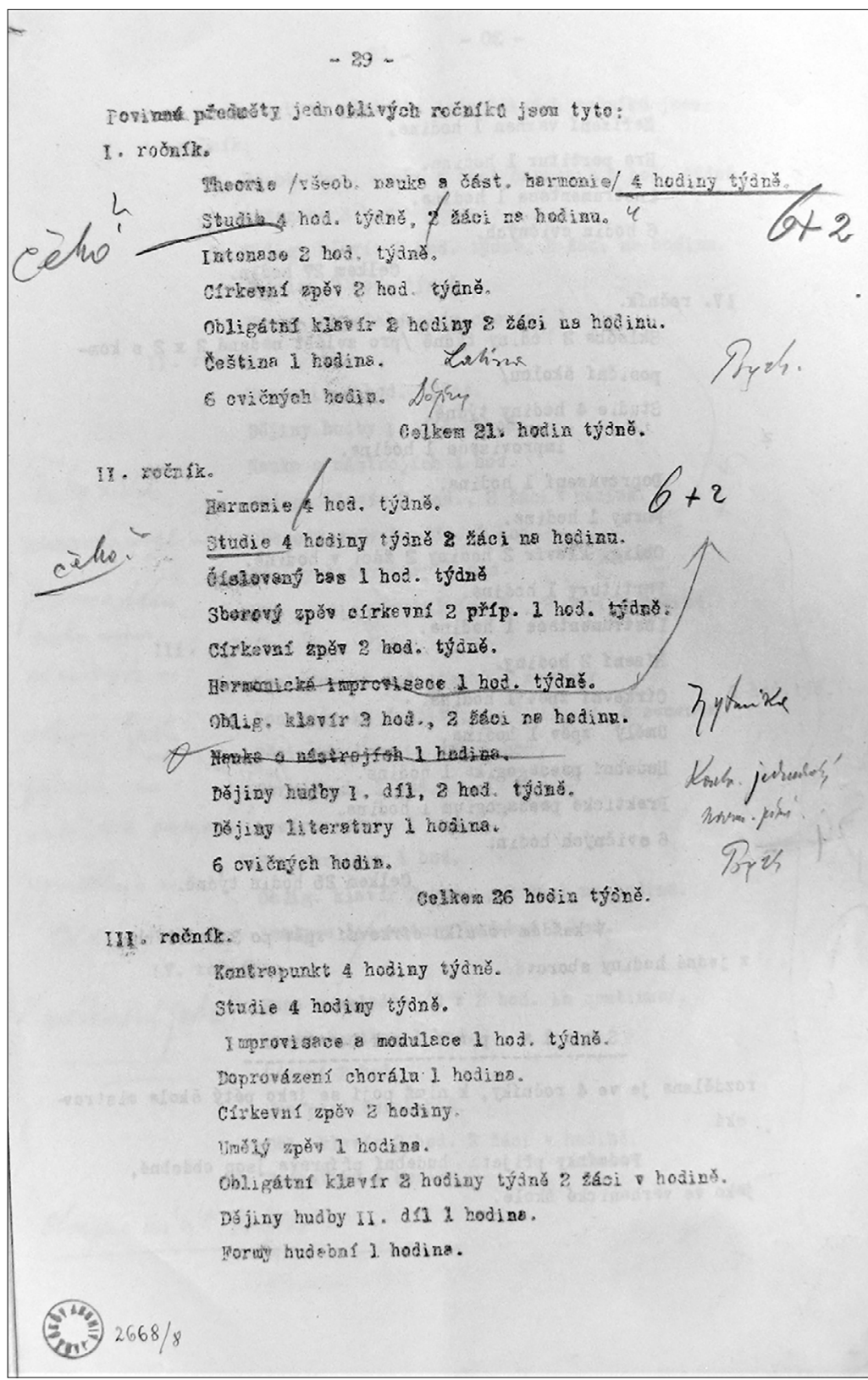

Obr. 2 Janáčkem připomínkovaná koncepce pražské konzervatoře, JA MZM, sign. K 2. 


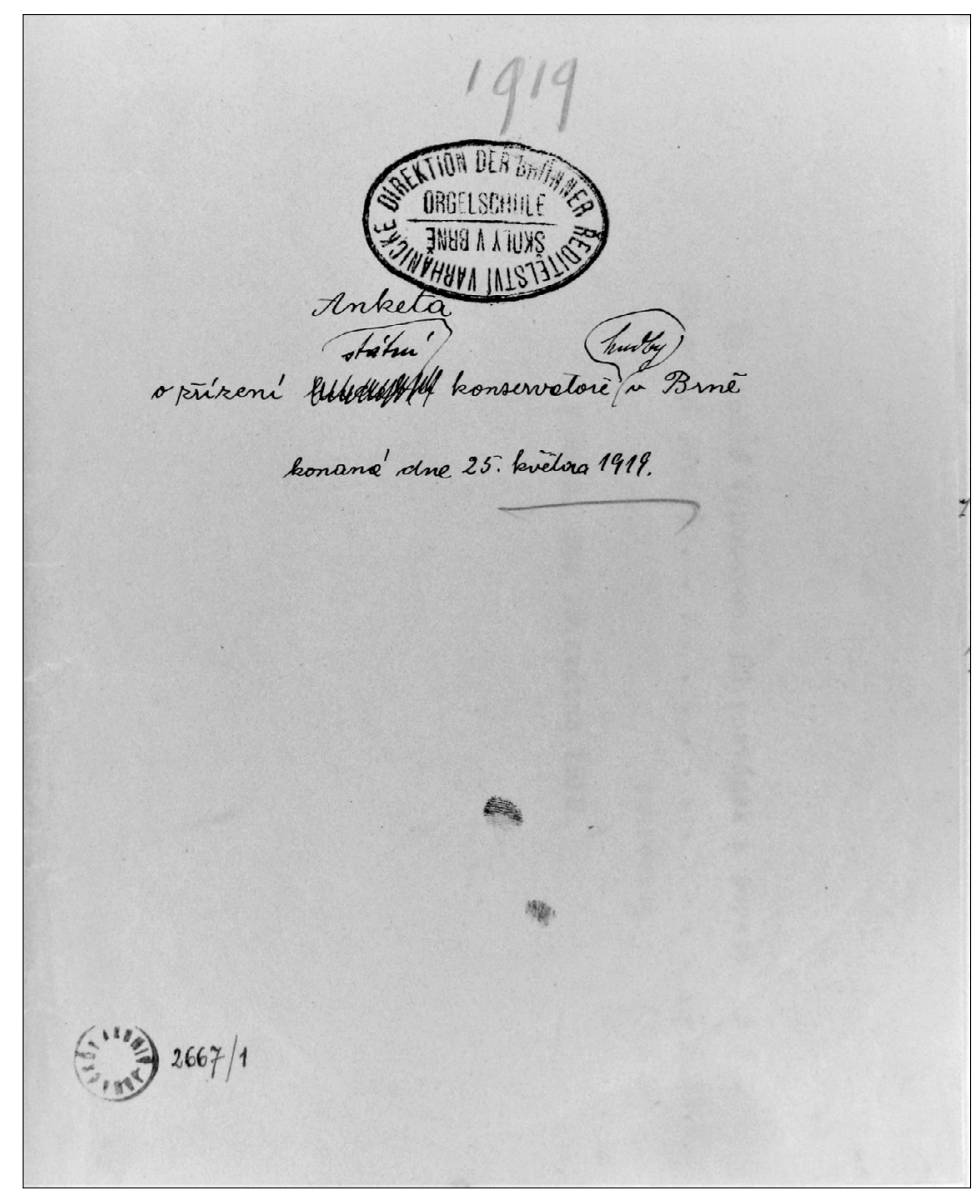

Obr. 3 Zápis brněnské Ankety z května 1919, JA MZM, sign. K 1. 


\section{Bibliography}

\section{Sources}

Agenda Ministerstva školství a národní osvěty: Národní archiv v Praze, zn. MŠ, fond Ministerstvo školství, Praha, kart. 3410, inv. č. 330 Brno.

Agenda školského a kulturního výboru Národního shromáždění československého: Archiv poslanecké sněmovny, fond RNS.

Zápisy ze schůzi Národního shromáždění československého, tisky návrhů jsou dostupné z: https:// www.psp.cz/eknih/1918ns/index.htm

Korespondence Leoše Janáčka je uložena v Janáčkově archivu Moravského zemského muzea; citováno z: ZAHRÁDKA, Jiří a kolektiv (ed.). Korespondence Leoše Janáčka [online]. Brno 2016.

Agenda varhanické školy a soukromé konzervatoře je uložena v Janáčkově archivu Moravského zemského muzea.

Korespondence Vladimíra Helferta je uložena v Oddělení dějin hudby Moravského zemského muzea.

Pozůstalost Jana Kunce je uložena v Oddělení dějin hudby Moravského zemského muzea.

\section{Literature}

CHLUBNA, Osvald. Vzpomínky na Janáčkův případ. Opus musicum, roč. 2, 1970, s. 281-83.

KUNC, Jan. Z historie brněnské konzervatoře. In Výročni zpráva za školni rok 1924/25, Brno: Nákladem Státní hudební a dramatické konzervatoře v Brně, 1925, s. 3-7.

KUNDERA, Ludvík. Soukromá konservatoř (1919/1920). In Brněnská konservatoř 1919-1945. Brno: Ředitelství státní hudební a dramatické konservatoře v Brně, 1947, s. 7-22.

PETRŽELKA, Ivan. Vzpomínka na Janáčkův případ. Opus musicum, roč. 16, 1984, s. 39-40.

STEINMETZ, Karel. „Janáčkův př́ípad“ a role některých Janáčkových žáků v něm. In Karel Steinmetz: Muzikologické studie. Ostrava: Ostravská univerzita, 2015, s. 86-91.

TRKANOVÁ, Marie. „Paměti: Zdenka Janáčková - můj život." Brno: Nakladatelství Šimon Ryšavý, 1998.

TRKANOVÁ, Marie. U Janácků. Praha: Panton, 1959.

TYRRELL, John. Janáček, Years of a Life. Volume II (1914-1928). The Lonely Blackbird. London: Faber and Faber, 2007.

WEYR, František. Paměti 2; Za republiky (1918-1938). Brno: Atlantis, 2001.

ZAHRÁDKA, Jiří. „Divadlo nesmí býti lidu komedii.“ Leoš Janáček a Národni divadlo v Brně. Brno: Moravské zemské muzeum, 2012.

ZOUHAR, Zdeněk. Jan Kunc. Praha: SPN, 1960. 